\title{
The Roots of Misalignment: Insights on Strategy Implementation from a System Dynamics Perspective
}

\begin{abstract}
This essay advances the study of strategic alignment by explaining how and why misalignment occurs. We begin by summarizing why IT and business strategies evolve in unintended ways, a phenomenon known as strategic drift. Using the causal loop diagramming approach of system dynamics, we observe that several sources of drift, potentially resulting in misalignment, are paradoxically built into the process of strategy formation and enactment itself. These linked subprocesses involve multiple actors at multiple levels of an organization and operate to promote (or hinder) strategic alignment. This paper contributes to the literature by enumerating and modeling both the top-down processes that can promote (or hinder) strategic alignment, as well as the less-studied bottom-up processes, ultimately yielding a more nuanced, dynamic, process-oriented understanding of strategic alignment. Directions for future research include the study of alignment at the process and group levels, as well as an exploration of settings where certain types of strategic drift and misalignment yield beneficial outcomes.
\end{abstract}

Keywords: strategic alignment, strategy, strategic IS planning, drift, governance, process theory, system dynamics, causal loop, feedback

(C) 2019. This manuscript version is made available under the CC-BY-NC-ND 4.0 license http://creativecommons.org/licenses/by-nc-nd/4.0/

Journal: The Journal of Strategic Information Systems

Available online: 26 October 2019

https://doi.org/10.1016/j.jsis.2019.101576 


\section{Introduction}

The alignment of an organization's business strategy with its IT strategy is a research topic of enduring importance. Strategic alignment has been and continues to be of keen interest to practitioners, a fact to which decades of industry surveys attest (Kappelman et al. 2019). This practitioner interest, in turn, has motivated researchers to publish an extensive body of work, identifying a host of antecedents and consequences, costs and benefits, processes and procedures related to alignment (Chan and Reich 2007). Interest in the topic remains strong, with workshops, special issues of journals, literature reviews, and metaanalyses both completed and planned (Bharadwaj et al. 2013; Chan and Reich 2007; Coltman et al. 2015; Gerow et al. 2014; Karpovsky and Galliers 2015).

Alignment is often viewed primarily as the result of top-down planning, communication, and control processes. We propose an alternative framing for strategic alignment, one that focuses not only on topdown processes initiated by executives, but also on the bottom-up processes initiated by users and managers. These less-frequently examined bottom-up processes are important for understanding alignment because they may lead to unintended deviations in an organization's business and IT strategies. While business and IT executives may conclude a planning process with coordinated and integrated plans, managers' and users' actions influence the way these plans are implemented, and instead of alignment, these actions may lead to misalignment.

Strategic drift from the original objectives (Ciborra 2000) takes place because users and managers have agency and may choose to improvise to deal with various challenges (Singh 2015), such as turbulent environments, ambiguous directives, resource shortages, political machinations, and IT systems that do not possess the desired functionality. While strategic alignment may have resulted if executives' plans had been implemented exactly as stated, the challenges of communication, the realities of user agency, and the dynamic business environment may lead to misalignment, with business strategy and IT strategy enacted in such a way that the two do not support one another. Our goal in this essay is thus to explicate causes of strategic drift and expand the discussion of how and why misalignment may occur. 
Our essay proceeds as follows. We begin by reviewing selected literature on strategic alignment, noting the limitations that arise from the prevalence of factor models rather than process models, and from firmlevel studies rather than process-, unit-, or subgroup-level studies. In the Theoretical Development section, we seek to address these limitations by building a model that identifies reasons for deviation from intended strategies, and ultimately for misalignment. We take a system dynamics perspective (Forrester 1961; Richardson 2012) on alignment in order to identify key processes at multiple levels within the organization. As we develop our system dynamics model, we also provide a series of propositions to highlight key relationships that bear future investigation. In the Discussion section, we explore the implications of our theorizing, observing that several potential sources of misalignment are built into the process of strategy formation and enactment, noting the sometimes serendipitous outcomes of drift and misalignment, and suggesting additional ways to enrich researchers' understanding of alignment. For the benefit of practitioners, we provide suggestions to help manage strategic drift and misalignment. In the Conclusion, we emphasize our intended contribution: the identification of linked processes involving multiple actors at multiple levels of the organization - processes that promote (or hinder) strategic alignment. Ultimately, our goal in this essay is to advance the study of strategic alignment by explaining how and why misalignment can occur.

\section{Literature review}

\subsection{Strategic alignment}

Strategic alignment has been defined as “...the degree to which the information technology mission, objectives, and plans support and are supported by the business mission, objectives, and plans" (Reich and Benbasat 2000, p. 82). This facet of business-IT alignment is recognized in IS literature as intellectual alignment (Gerow et al., 2014), or simply as strategic alignment (Baker et al., 2011; Sabherwal et al., 2001) to emphasize the alignment between business and IT strategies. Strategic alignment is the term we will adopt throughout the remainder of the paper ${ }^{1}$. Literature reviews and meta-analyses consistently bear out

\footnotetext{
${ }^{1}$ Other facets of business-IT alignment examine the harmonization of business strategy and business infrastructure (business alignment), IT strategy and IT infrastructure (IT alignment), business infrastructure and IT infrastructure (operational alignment), business strategy and IT infrastructure
} 
that business and IT performance improve when firms experience a high level of strategic alignment (Chan and Reich 2007; Gerow et al. 2014).

Strategic alignment is pursued in a dynamic competitive context (Agarwal and Sambamurthy 2002; Hirschheim and Sabherwal 2001; Piccoli and Ives 2005; Sabherwal et al. 2001), and one theoretical base that is increasingly being used in the study of strategic alignment is the dynamic capabilities framework (DCF) (Teece et al. 1997). In this framework, internal technological, organizational, and managerial processes enable firms to generate economic rents in settings of rapid change (Helfat et al. 2009; Teece et al. 1997). The DCF emphasizes the importance of managerial capabilities, which are seen as being valuable, rare, difficult to imitate, and difficult to substitute because firms lack the organizational capacity to quickly develop new competencies (Dierickx and Cool 1989). Dynamic capabilities enable firms to adjust their strategies and resources to maintain and sustain competitive advantage (Wade and Hulland 2004).

We believe that the dynamic capabilities framework is a suitable theoretical base from which to study strategic alignment. Researchers have noted that achieving a high degree of strategic alignment is a capability built upon a specific set of IT management competencies (Gupta et al. 1997; Peppard and Ward 2004). To the extent that alignment results "from skill rather than luck, it is reasonable to regard alignment skill as a strategic resource capable of generating economic rents" (Powell 1992, p. 119). Leaders must continually evaluate and renew IT resources and capabilities to avoid falling into misalignment (Benbya and McKelvey 2006). Firms that are able to build processes to promote and achieve a high degree of alignment between their business and IT strategies, even in the midst of a changing competitive environment, possess a dynamic organizational competency in the area of strategic alignment (Baker et al. 2011; Pelletier and Raymond 2014; Schwarz et al. 2010). Thus, the ability to promote and achieve a high degree of alignment is a basis upon which competitive advantage can be built.

(cross-domain alignment), and IT strategy and business infrastructure (another type of cross-domain alignment) (Gerow et al., 2014). Each of these facets of business-IT alignment we place outside the scope of our paper, focusing solely on strategic alignment, which is the alignment between business strategy and IT strategy. 
We seek to add to the existing understanding of strategic alignment by describing the constellation of organizational processes, administrative routines, and employee activities that influence alignment. Some strengthen and promote alignment, while others weaken and impede it. Some are initiated by senior management and operate in a top-down manner, while others are driven by employees and influence alignment from the bottom-up.

\subsection{Limitations of strategic alignment research}

In spite of the enduring interest in strategic alignment and the vast amount of research that has been conducted, limitations exist. First, IS researchers have noted a frequent use of variance models, but a comparative dearth of research that builds or utilizes process models (Chan and Reich 2007). One result of this preference for variance models is that extant research emphasizes the "what" of alignment - that is, the variables and constructs - but provides little detail regarding the "how" - the processes and routines (Ciborra 1997; Pelletier and Raymond 2014). The actions that lead towards (and away from) alignment, as well as the sequence of activities and the timeline that is an inherent part of alignment, thus remain understudied (Chan and Reich 2007; Sabherwal and Chan 2001; Street 2006).

The emphasis on factor models has yielded a traditional model of strategic alignment where alignment is a measurable outcome of business and IT strategies; and with alignment leading, in turn, to improved business performance ${ }^{2}$ (e.g., Sabherwal et al. 2001, Chan et al. 1997, Venkatraman 1989, Tallon 2007, Hirschheim et al 2001). We nevertheless note that this traditional model does not capture the reality of strategic co-evolution (Agarwal and Sambamurthy 2002), where IT and business capabilities develop reciprocally and iteratively over time as they adapt to one another. Nor does it include strategic drift, a phenomenon observed when information systems "deviate from their planned purpose for a variety of reasons often outside anyone's control" (Ciborra 2000, p. 4). The traditional model does not reflect the

\footnotetext{
${ }^{2}$ Venkatraman (1998) describes six common perspectives of alignment in the literature. We focus here on the characterization of alignment as profile deviation (i.e., "the degree of adherence to an externally specified profile"). See Venkatraman (1989) for a description of all six characterizations. When operationalizing profile deviation, we advocate the approach of Tallon et al. (2016), where the removal of the absolute value or square term allows the identification of misalignment that takes the form of "IT shortfall" where IT strategy does not adequately support the business strategy or of "IT slack" where the IT strategy prescribes capabilities beyond those required by the business strategy. We reserve the application of our arguments and ideas to other characterizations of alignment for future research.
} 
reality that strategies evolve in an uneven, nonlinear fashion over the course of time and in response to changes in the competitive environment (Sabherwal et al. 2001; Street 2006). Furthermore, it does not incorporate feedback mechanisms, emergent outcomes, or the bottom-up processes that give shape to IT strategies (Ciborra 2000).

While seminal research does well to distinguish between leaders' intended IT strategy and the firm's realized IT strategy (Chan et al. 1997, p. 126; Sabherwal and Chan 2001, p. 13), this is a distinction whose theoretical importance has not been fully appreciated. Research on strategic alignment could be enriched by directly comparing intended IT strategy to realized IT strategy and, perhaps more significantly, by examining reasons why IT strategy is not realized as it was originally intended. Strategic management research has much to offer to the discussion of why strategies often deviate from leaders' original intentions, including insights on the importance of explicit strategic plans, clear communication from leaders, employees' acceptance and ownership of management's strategic aims, and the degree of environmental dynamism (Baets 1992; Mintzberg 1978; Mintzberg and Waters 1985). We see the DCF as offering additional opportunities for theoretical development, inviting the examination of alignment at a more granular level, as it enables the enumeration and description of the specific managerial processes, routines, and activities upon which the dynamic strategic alignment competency is built. In the upcoming Theoretical Development section of this paper, we employ the causal loop diagramming approach of system dynamics as we return to this discussion of how and why intended strategies may not be realized, and the processes of strategic deviation that cause strategic alignment to be different in either form or function from what was originally intended.

Second, much alignment research examines issues at the organizational or firm level, encouraging IS researchers to remark that beneficial work remains to be done at additional levels of analysis (Benbya and McKelvey 2006; Chan and Reich 2007; Tallon 2007; Tallon et al. 2016; Tallon and Pinsonneault 2011; Wagner et al. 2014). Specifically, operational and process levels of analysis have been suggested as areas for examination (Benbya and McKelvey 2006). The group and individual levels have been suggested as well (Ravishankar et al. 2011). At these levels, the social dimension of alignment (Campbell et al. 2005; 
Chan and Reich 2007; Sledgianowski and Luftman 2005) affects the level of shared knowledge between IT and business executives (Leidner et al. 2017; Preston and Karahanna 2009; Rau 2004; Reich and Benbasat 2000) and how well the IT unit can support the firm (Tarafdar and Qrunfleh 2009). Furthermore, there is growing interaction between technology and people (Orlikowski and Scott 2008), which is creating new and heretofore unobserved ways for users to influence strategy from the bottom up. Our model therefore also seeks to identify the processes of strategy implementation, the implications of communication practices at the operational level of analysis, and the ways in which users are able to modify strategies, which can result in misalignment.

\section{Theoretical development}

\subsection{Strategic alignment and the system dynamics approach}

System dynamics is a methodology and modeling technique for understanding the behavior of complex, nonlinear systems. It was originally developed for application in managerial settings, but has since been applied to a host of economic, social, and ecological systems (Forrester 1961; Richardson 2012). It is wellsuited to the examination of dynamic systems with interdependence, mutual interaction, feedback, and circular causality.

The system dynamics approach begins by modeling a system to be studied dynamically, generally utilizing the causal loop diagramming technique. Loops indicating feedback and circular causality reveal that the concept of endogenous change is fundamental in system dynamics. Exogenous factors are triggers of system behavior, but the causes are more often contained within the system itself. Feedback loops may be either reinforcing and amplify deviations from the initial state for some component of the model, or they may be balancing and counteract deviations. After modeling through causal loop diagramming, stocks (indicating the level of a factor or variable), flows (rates and directions of change), and time delays are added to the diagram. Mathematical equations can then be developed linking the stocks and flows. A final step is the mathematical simulation of the system.

While the initial disciplinary home for system dynamics was operations management, it has also been employed in management and IS research. In IS research, the development of software for system dynamics 
modeling and simulation has been demonstrated (Druckenmiller and Acar 2009). System dynamics has also been applied to develop and analyze formal mathematical models through simulation (Dutta 2001; Dutta and Roy 2005; Fang et al. 2018) and to study technology implementation (Black et al. 2004; Choi et al. 2010; Li and Madnick 2015). Perhaps more often, however, system dynamics has been employed in management and IS research as an approach for conceptual (non-mathematical) modeling to assimilate findings from prior literature or to represent findings from interpretive case research (Azoulay et al. 2010; Clark et al. 2007; Perlow et al. 2002; Repenning and Sterman 2002; Rudolph and Repenning 2002; Sutanto et al. 2008-9; Van Oorschot et al. 2013).

We employ causal loop diagramming in this paper to integrate the constructs and relationships that are associated with strategic implementation and alignment in extant literature ${ }^{3}$. Our causal loop diagram illustrates the system of alignment-related activities, its components, and its feedback loops. Our model has been developed by examining literature on strategy implementation and strategic alignment, including the identification of key constructs and relationships. As we describe our diagram in the upcoming subsections, each construct is defined using prior literature, then the relationship from each construct to its related constructs is described, and finally a visual presentation is given.

We see system dynamics as a particularly useful tool for examining strategic alignment for several reasons. Strategic alignment has been extensively discussed by researchers, and existing research features multiple perspectives and identifies a number of factors and processes that support (or hinder) alignment (Chan and Reich 2007; Karpovsky and Galliers 2015). As this research stream has developed, researchers have increasingly acknowledged complexities such as co-evolution, punctuated equilibrium, feedback, mutual adaptation, and emergent outcomes - each of which can exist at multiple levels of the organization (Agarwal and Sambamurthy 2002; Benbya and McKelvey 2006; Ciborra 2000; Karpovsky and Galliers 2015; Sabherwal et al. 2001; Tallon 2007; Tallon 2011). These complexities test the limitations of existing linear models - and indicate that the reality of strategic alignment may require a more nuanced explanation

\footnotetext{
${ }^{3}$ We reserve parametric modeling for future research.
} 
than has previously been presented. To address the complexity of strategic alignment and its related processes, we therefore look to the system dynamics approach, an approach that enables us to develop a model that is dynamic, nonlinear, and feedback-oriented.

\subsection{Model structure}

\subsubsection{Business strategy implementation and evaluation}

An important distinction has been made in prior literature between "leadership plans and intentions," which are the intended business strategy, and "what the organization actually did", the realized business strategy (Mintzberg and Waters 1985, p. 257). Drift from intended strategy to realized strategy often occurs in business strategy implementation, and it has been argued that this type of drift is almost inevitable. For a strategy to be realized exactly as intended, three conditions must exist (Mintzberg and Waters 1985). First, the organization must first have precise, concrete, and detailed intentions. That is, the intended strategy must be explicit and specific if it is to be understood by employees and faithfully implemented. This is not always the case, however, with many organizations having unknown, unclear, or ambiguous intended business strategies (Baets 1992; Reich and Benbasat 2000). Second, the organization must also have intentions that either (a) emanate from senior leaders and are accepted fully by the employees, and/or (b) are shared wholeheartedly among the employees (Mintzberg and Waters 1985). If employees do not accept, internalize, and "own" the strategy that has been proposed by senior leaders, they will not be willing or able to implement it. Employee support and buy-in is imperative if intended strategies are to be fully realized. Difficulties with communication and employee support may result in some or all of the intended strategy being unrealized. Third, no external environmental force interferes with the implementation of the intended strategy (Mintzberg and Waters 1985). The reality of environmental dynamism means that it will be difficult to implement even the most clearly-communicated, thoroughly-supported intended strategy without modification. Finally, after the intended business strategy is developed and communicated, after a level of employee support has formed, after some portion of the intended strategy is not realized, and after emergent strategic initiatives influence the realized strategy, a feedback process begins (Mintzberg and Waters 1985). In this process, leaders may observe the difference between the intended business strategy 
and the realized business strategy, or may notice some aspect of the realized business strategy that can be improved and use this information to reformulate a new intended strategy.

We now extend this explanation of the strategic implementation and evaluation process to begin to build a causal loop diagram. Explicit, clear, and precise intended business strategies have a positive influence on the communication of business strategy. Conversely, an unclear, imprecise, or inexplicit intended strategy decreases the likelihood that intentions can be effectively communicated. In real-world settings, communication of strategies will likely be imperfect. Clear, detailed communication in which every aspect of the meaning embedded in the strategic statement is delivered to employees is possible in theory, but unlikely in practice (Balogun 2006; Balogun and Johnson 2005). Even the best efforts of management will still only imperfectly communicate the strategic intent to employees. Moreover, sometimes, even when the communication is clear, it may not be effective, in that it does not persuade employees who hold different views to change their minds. This may be because of reasons such as a poorly-chosen method of communication, limited ability to "cast strategic vision" on the part of the top management team, inattention from employees, or cultural and language barriers (Jarzabkowski and Sillince 2007). The inexorable process of deviation from the intended strategy has begun.

Once the intended business strategy has been communicated to employees, a level of employee support forms. Given that employees may not clearly understand every aspect of the strategy, may have views that differ from those of senior leaders, and may have not been effectively persuaded to modify them, it is unlikely that complete, unanimous support will materialize (Lewis 2007). Sometimes, poor communication may lead to reduced support and the formation of coalitions within the organization that may resist the strategy or support alternate plans. The implication of this is that the strategy supported by the employees is somewhat different from what senior management intended. Elements of the strategy, or possibly the entire strategy itself, may be unrealized (Mintzberg and Waters 1985). Thus, there is a positive relationship between communication and employee support, where clearer communication enables a higher level of employee support, and where unclear communication hampers the level of employee support. Also, there is a negative relationship between communication and unrealized strategy, where clearer communication 
reduces the likelihood that strategy will be unrealized, and where unclear communication increases the likelihood that strategy will be unrealized.

A high level of employee support will enable the realization of the intended business strategy. On the other hand, a low level of support indicates that the realized strategy will differ from original intentions. Strategic initiatives that are not fully supported cannot be fully implemented (Mintzberg and Waters 1985). Thus, a positive relationship exists from employee support to realized business strategy as well.

At the same time, it should be noted that a low level of employee support indicates an increased likelihood of unrealized strategy (a negative relationship). Furthermore, a low level of employee support presages the potential development of an emergent strategy (while conversely, a high level of employee support for the intended, communicated strategy dampens the development of an alternate emergent strategy); this is also a negative relationship.

The realized strategy will also differ from original intentions as a result of changes in the competitive environment that have occurred during the strategy implementation process (Newkirk and Lederer 2006). By the time an intended strategy is realized, a different strategy (even if only slightly different) will likely be more valid and appropriate (Henderson and Sifonis 1988). Stasis is rarely observed in the competitive environment. As a result, the most likely scenario is that the realized business strategy, with its requisite resources, will exhibit deviation or drift from the original intent. Environmental dynamism therefore has a negative relationship with strategic implementation; the greater the level of dynamism and change, the less likely the realized business strategy is to resemble the originally intended one. Note that a high level of environmental dynamism can increase the likelihood of an emergent business strategy forming, which is a positive relationship, possibly one that is adaptive and better suited to conditions that exist at the moment of strategic implementation/realization than the one developed at an earlier point in time. And also, a negative relationship exists between the presence (absence) of an emergent strategy and a high (low) level of strategic realization.

Finally, the feedback relationship in the process of strategy formation will likely result in adjustments to strategy and the specificity of strategic statements in the next time period. A negative relationship exists 
here: when the realized business strategy displays a high degree of agreement with the intended business strategy, there will be less need for strategic change or for increases in the specificity and detail of the intended business strategy in the next time period. Equally, when the realized business strategy displays a low degree of agreement with the intended business strategy, significant strategic changes are more likely, with a higher degree of strategic statement specificity than in the past.

To summarize, while it may be possible for an organization to clearly and explicitly define its strategic intentions, the additional requirements of explicit and unambiguous communication, followed by unanimous assent from all members of the organization, and the necessity of an environment that is predictable, benign, or controllable are unlikely to be achieved. There is thus a low possibility of observing what has been termed a deliberate strategy, one that is realized exactly as intended (Mintzberg and Waters 1985). Instead, it seems highly probable that some degree of drift from intended business strategy to a realized business strategy will occur. Feedback then occurs, with a new business strategy formulated to respond to new environmental conditions, to promote the more complete implementation of what was previously intended, or some combination of the two. During this process, some elements of the intended strategy may be unrealized, and new, emergent elements may be incorporated into the final, realized strategy. This causal loop is therefore a balancing loop, one that includes drift-inducing variables as well as a corrective feedback mechanism to address the strategic drift. The completed loop is depicted in Figure 1, where "+" signs denote a positive relationship (e.g., a clear and specific intended business strategy increases the likelihood that it can and will be communicated clearly), and a "-" symbol denotes a negative relationship (e.g., as environmental dynamism increases, the less likely the realized strategy is to resemble the intended strategy). Environmental dynamism is exogenous in this structure, illustrated as a trigger of strategic drift, while the other constructs are shown as endogenous. Construct definitions appear immediately below the figure. 


\section{Figure 1}

Business strategy implementation and evaluation structure.

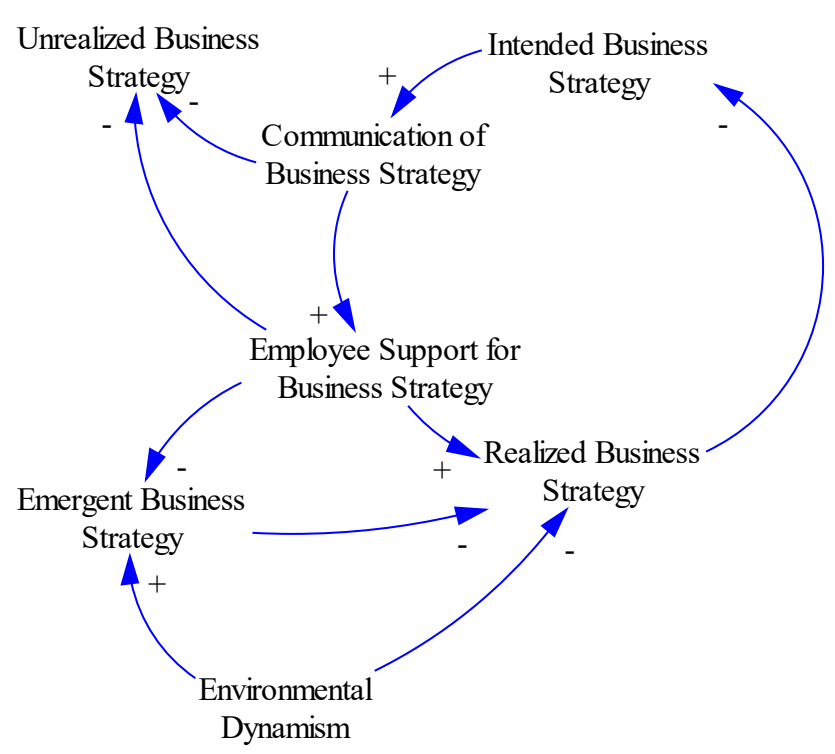

\begin{tabular}{|c|c|c|}
\hline $\begin{array}{l}\text { Causal Construct } \\
\text { definition }\end{array}$ & Response Construct & Supporting Literature \\
\hline $\begin{array}{l}\text { Intended Business Strategy } \\
\text { The plans and intentions of an organization's leadership team, } \\
\text { which can vary in their explicitness and specificity }\end{array}$ & $\begin{array}{l}\text { Communication of } \\
\text { Business Strategy }\end{array}$ & $\begin{array}{l}\text { (Baets 1992; Mintzberg 1978; } \\
\text { Mintzberg and Waters 1985; } \\
\text { Reich and Benbasat 2000). }\end{array}$ \\
\hline $\begin{array}{l}\text { Communication of Business Strategy } \\
\text { Clarity of transmission of the intended business strategy from } \\
\text { leaders to employees using written, verbal, or other means }\end{array}$ & $\begin{array}{l}\text { Employee Support } \\
\text { for Business Strategy }\end{array}$ & $\begin{array}{l}\text { (Jarzabkowski and Sillince } \\
\text { 2007; Mintzberg 1978; } \\
\text { Mintzberg and Waters 1985). }\end{array}$ \\
\hline Communication of Business Strategy & $\begin{array}{l}\text { Unrealized Business } \\
\text { Strategy }\end{array}$ & $\begin{array}{l}\text { (Mintzberg 1978; Mintzberg and } \\
\text { Waters 1985) }\end{array}$ \\
\hline $\begin{array}{l}\text { Employee Support for Business Strategy } \\
\text { Degree of acceptance, agreement, and support for leadership's } \\
\text { communicated strategic plans }\end{array}$ & $\begin{array}{l}\text { Unrealized Business } \\
\text { Strategy }\end{array}$ & $\begin{array}{l}\text { (Mintzberg 1978; Mintzberg and } \\
\text { Waters 1985) }\end{array}$ \\
\hline Employee Support for Business Strategy & $\begin{array}{l}\text { Realized Business } \\
\text { Strategy }\end{array}$ & $\begin{array}{l}\text { (Lewis 2007; Mintzberg 1978; } \\
\text { Mintzberg and Waters 1985). }\end{array}$ \\
\hline Employee Support for Business Strategy & $\begin{array}{l}\text { Emergent Business } \\
\text { Strategy }\end{array}$ & $\begin{array}{l}\text { (Mintzberg 1978; Mintzberg and } \\
\text { Waters 1985) }\end{array}$ \\
\hline $\begin{array}{l}\text { Environmental Dynamism } \\
\text { Rate of change in a firm's competitive environment, including } \\
\text { the rate at which consumer preferences change, competitors } \\
\text { enter the market, and new technologies emerge }\end{array}$ & $\begin{array}{l}\text { Emergent Business } \\
\text { Strategy }\end{array}$ & $\begin{array}{l}\text { (Henderson and Sifonis } 1988 \text {; } \\
\text { Mintzberg 1978; Mintzberg and } \\
\text { Waters 1985) }\end{array}$ \\
\hline Environmental Dynamism & $\begin{array}{l}\text { Realized Business } \\
\text { Strategy }\end{array}$ & $\begin{array}{l}\text { (Henderson and Sifonis } 1988 \text {; } \\
\text { Mintzberg 1978; Mintzberg and } \\
\text { Waters 1985) }\end{array}$ \\
\hline $\begin{array}{l}\text { Emergent Business Strategy } \\
\text { A pattern in a stream of decisions that has developed despite } \\
\text { (or in the absence of) intentions }\end{array}$ & $\begin{array}{l}\text { Realized Business } \\
\text { Strategy }\end{array}$ & $\begin{array}{l}\text { (Henderson and Sifonis 1988; } \\
\text { Mintzberg 1978; Mintzberg and } \\
\text { Waters 1985) }\end{array}$ \\
\hline $\begin{array}{l}\text { Realized Business Strategy } \\
\text { Actions that the organization actually took, assessed as the } \\
\text { degree of agreement with the intended business strategy }\end{array}$ & $\begin{array}{l}\text { Intended Business } \\
\text { Strategy }\end{array}$ & $\begin{array}{l}\text { (Chan et al. 1997; Mintzberg } \\
\text { 1978; Mintzberg and Waters } \\
\text { 1985) }\end{array}$ \\
\hline
\end{tabular}


We highlight here that environmental dynamism acts as an exogenous trigger for the system behaviors seen in Figure 1. Thus, the model presented in Figure 1 implies the existence of the following set of propositions, beginning with

Proposition la: Strategic drift is more likely in organizations that face a high level of environmental dynamism.

Additionally, Figure 1 indicates that when organizations are willing to incorporate emergent ideas that result from employee initiatives and environmental dynamism, drift will result. This willingness to deviate from plans and embrace employee-led, bottom-up initiatives varies from firm to firm. Firms that expect new ideas and creativity from employees; encourage risk-taking; tolerate failure; promote learning; champion product, process, and administrative innovations; and view continuous change as a conveyor of opportunities are said to have an entrepreneurial culture (Eisenhardt and Tabrizi 1995; Ireland et al. 2003; Kirzner 1973; Shane and Venkataraman 2000). These characteristics of entrepreneurial cultures predispose a firm to embrace emergent ideas. Therefore, we state

Proposition 1b: Strategic drift is more likely when organizations have innovative, entrepreneurial cultures.

Furthermore, in spite of the negative connotations of the word "drift", strategic drift from intended to realized strategy has the potential to be either beneficial or deleterious for an organization. In settings of high environmental dynamism, strategic drift should produce beneficial effects because it provides an adaptive mechanism, a way to enact a contextually-appropriate realized strategy, even in the presence of a contextually-outdated intended strategy. In settings of low environmental dynamism, however, strategic drift may be either beneficial or deleterious. Drift could produce beneficial effects in settings of low environmental dynamism when intended business strategies do not match their environments, because drift provides the opportunity to improve the relationship between strategy and the competitive environment. In contrast, strategic drift could yield deleterious effects in settings of low environmental dynamism when organizational strategies match their environments; this is because drift indicates a misallocation of resources, a scenario where effort is being spent on nonessential or suboptimal activities. 
Proposition 1c: In settings of high environmental dynamism, strategic drift from the intended business strategy can produce beneficial effects.

Proposition 1d: In settings of low environmental dynamism, strategic drift from the intended business strategy produces deleterious (beneficial) effects when organizational strategies match (do not match) their environments

\subsubsection{IT strategy implementation and evaluation}

Following from the section on business strategy immediately above, we argue that drift from an intended IT strategy to a realized IT strategy can occur for similar reasons. That is, drift occurs when the IT strategy is communicated imprecisely, when employee support is incomplete, when the competitive environment changes, and when emergent IT strategies form.

First, communication between business and IT executives has been repeatedly emphasized as a way to develop an IT strategy that is clear, feasible, implementable, and ultimately aligned with the overall business strategy. Important initial steps in strategic IS planning (SISP) include business and IT executives collaborating to gather information about the competitive environment, consider new technological and strategic opportunities, and discuss how IT capabilities can help the organization maintain flexibility and competitive advantage (Grover and Segars 2005; Newkirk and Lederer 2006; Peppard and Ward 2004; Schwarz et al. 2010; Wade and Hulland 2004). As SISP proceeds, CEO participation in IT planning and CIO participation in business planning helps firms clearly articulate an IT strategy (Kearns and Lederer 2003). Similarly, having the CIO as a formal member of the top management team promotes a common vision for the use of IT in the firm (Agarwal and Sambamurthy 2002). Furthermore, evaluating senior executives by noting their innovative use of IT, allowing IT to demonstrate innovative ideas, embedding IT in multiple business processes, and emphasizing the ways IT can provide strategic flexibility are all ways to communicate IT strategy and its importance across the business (Agarwal and Sambamurthy 2002).

When these various sub-processes are an integral part of strategy planning and execution, this will facilitate the development of a specific, clearly-articulated IS/IT strategy that can be communicated to managers and employees in a way that facilitates implementation as intended. In organizations with mature strategic IT communications processes, the understanding of IT strategy by employees, including even non- 
IT department employees, is pervasive, exists at all levels of the organization, and is facilitated by multiple liaisons at these levels (Luftman 2000). In the absence of cross-departmental and multilevel communication, leaders will find it challenging to develop a shared understanding and clearly communicate their strategic plans to their managers and other employees (Benbya and McKelvey 2006). A positive relationship exists between clear strategic IT intentions and the communication of those intentions. Furthermore, based on the aforementioned research, it can be observed that clear communication of the intended IT strategy is an essential pre-requisite to gain employee understanding and support. A positive relationship thus exists between communication of the IT strategy and employee support for the IT strategy.

When communication clarity is low, the likelihood that intended strategy will be unrealized increases, and alternately, a high degree of clarity reduces the likelihood of unrealized strategic initiatives (Ciborra 2000; Luftman 2000). This indicates a negative relationship. Similarly, when there is a low level of employee support, the likelihood of unrealized strategy increases (and when there is a high level of support, the likelihood of unrealized strategy decreases), again a negative relationship.

Second, while strategies are developed by senior leaders, they are implemented at the lower levels of an organization's hierarchy. This makes it important to study the actions of employees (end-users) and middle managers in the context of alignment (Chan and Huff 1992; Hsiao and Ormerod 1998; Leidner et al. 2017; Ravishankar et al. 2011), and also to identify potential causes and mechanisms for bottom-up effects (Klein and Kozlowski 2000a; Klein and Kozlowski 2000b).

As we have noted, one potential avenue through which drift could occur is when employees do not accept their organization's strategic objectives relating to IT. Ample evidence exists in research of employees not accepting the intentions of management. Employees who disagree with their organization's IT plans may refuse to comply, either actively or passively. User actions may be seemingly benign, such as when non-use of a system takes place. Non-use can occur when users are unaware of a system's existence, are inadequately trained to use it, or fear the technology (Markus 1983). User actions can also be deliberate but subtle, such as when shadow systems are created or when workarounds are preferred (Ciborra 2000; Gasser 1986; Rondeau et al. 2006). Deliberate resistance occurs for a variety of reasons, 
such as user characteristics and system design deficiencies (Venkatesh et al. 2003). Low levels of usability, where significant effort is required to complete tasks using a system (Venkatesh 2000), or low levels of usefulness, where usage of a system will not meaningfully enhance job performance (Bhattacherjee and Premkumar 2004) can lead to resistance. Deliberate resistance can also occur because of some way in which a feature of the system interacts with the organizational context, such as when a new information system precipitates a change in users' political status, level of formal organizational power, and/or access to information (Lapointe and Rivard 2005; Markus 1983). Additionally, users can actively and purposefully deviate from and subvert intended IT strategies by, for example, resisting the use of new information systems, or sabotaging them (Ciborra 2000). The level of aggression with which new systems are resisted depends on user characteristics, system characteristics, and sociotechnical interactions; these forms of resistance can be particularly noticeable when distinct subcultures or workgroups with strong identities exist within the organization (Lapointe and Rivard 2005; Ravishankar et al. 2011).

The ability of users to initiate drift may be growing. Within the last decade, there has been a shift in the workforce and employees are now more educated, more tech-savvy, and more aware of technologies than their predecessors. Growing levels of IT literacy mean that employees increasingly possess the skills and knowledge to use an IT system to obtain, transfer, view, modify, analyze, and understand information (Martin 2008). "When computer-savvy young people are confronted with older, more difficult-to-use technologies at work, they get frustrated. There's a good chance that they'll find their own 'work-arounds' that allow them to use their own devices, regardless of company policy" (Twentyman 2011, p. 2). Wellknown examples include the widespread user push to use iPhones in corporate environments in spite of nontrivial security issues (Kaneshige 2010), and even former U.S. President Barack Obama's request for the White House to alter its IT security policy to allow him to carry a smartphone (Stewart 2009). Still another illustration of this trend towards tech-savvy users is seen in the growth of bring-your-own-device (BYOD) computing environments. CIOs are concerned about the growing number of BYOD-related issues, which have arisen because of the growing consumerization of IT and the flexibility and ease with which users can add or subtract different hardware and software components from IT platforms (Bergstein 2012; 
Messmer 2013). Furthermore, it has been noted that as new IT capabilities are introduced, either directly by the firm or in the broader marketplace, the needs of users change and co-evolve with these capabilities in potentially unforeseeable ways (Benbya and McKelvey 2006; Orlikowski and Scott 2008). Users are thus a source of strategic evolution, emergent IT initiatives, change, and drift.

End-users are not the only employees of interest in the discussion of drift, however. The role of middle managers in strategic management is of growing interest (Hsiao and Ormerod 1998; Leidner et al. 2017; Nan 2011; Raes et al. 2011; Wooldridge et al. 2008). Their actions provide another bottom-up mechanism that may lead to drift. The senior managers who develop a firm's strategy usually lack middle managers' ability to decipher the unclear relationship between a firm's capabilities and its performance (King and Zeithaml 2001). This makes middle managers more important in developing and carrying out the actions needed to develop a firm's capabilities (Wooldridge et al. 2008).

Middle- and lower-level managers, in IT and elsewhere, may "sell” issues to senior managers to induce organizational change (Dutton et al. 2001). These individuals sell issues by directing the attention and understanding of their seniors toward events and trends that may affect their group's or department's performance (Dutton and Ashford 1993). Issue-selling takes various forms, such as packaging, presentation, types of appeals, and bundling issues together (Dutton and Ashford 1993). Thus, altered IT strategies could emerge from middle managers' exhortations, and these strategies may sometimes be in conflict with pre-existing top-down strategies. This is more likely to occur in organizations that are younger, since few dominant norms have been established, and in those that are larger, since size hinders integration and increases the number and variety of goals pursued (Cyert and March 1963).

In summary, a positive relationship exists between employee support for the intended IT strategy and the realized IT strategy. A high level of support leads to a realized IT strategy that closely resembles the intended IT strategy, while a low level of support, for a variety of reasons and through a variety of mechanisms, augurs for a decreased resemblance between the intended and realized IT strategies.

At the same time, we observe that a low level of employee support augurs for the formation of an emergent strategy (conversely, a high level of employee support would slow the formation of any emergent 
strategy). Thus, a negative relationship exists between employee support for the IT strategy and an emergent IT strategy.

The third requirement for a strategy to be realized exactly as intended is that no external environmental force can interfere with the implementation of the strategy. Indeed, in IS research, it has been noted that alterations in strategy can occur, and in some cases should occur, because of changes in the competitive environment (Henderson and Sifonis 1988; Tanriverdi et al. 2010). Case study evidence reveals that one of the triggers of revolutionary change in IT strategy is a shift in the competitive environment (Sabherwal et al. 2001). New technological resources may emerge during the time between strategy formulation and implementation (Yoo et al. 2010). These technologies may enable the development of new products, processes, or services. Alternatively, new technologies may render obsolete some portion of the existing products, processes, or services, or the entire strategic thrust that supports them (Brynjolfsson and McAfee 2014). Conversely, environmental stability promotes strategic alignment as strategies are realized as they were initially planned and intended (Kearns \& Lederer, 2004). Thus, a negative relationship exists between environmental dynamism and the realized IT strategy. Low levels of environmental dynamism enable the realized IT strategy to bear a high resemblance to the intended IT strategy while high levels of dynamism do the opposite.

Furthermore, high levels of environmental dynamism promote the development of emergent IT strategy (and low levels of dynamism reduce the likelihood of emergent IT strategy forming), a positive relationship. The presence of an emergent IT strategy is, in turn, a factor that shapes the realized IT strategy, with a strong, pronounced emergent strategy reducing the similarity of the realized strategy to the intended strategy, a negative relationship.

Figure 2 illustrates the relationships that we have described. The existence of an explicit intended IT strategy has a positive influence on the ability of the firm to communicate that strategy to employees. The link from strategic communication to employee support is also positive; clear communication begets a high level of support. At the same time, the reality is that communication is often imperfect and incomplete. Despite the best efforts of senior management, meaning can be "lost in translation" to employees, hindering 
the amount of support that can form and causing some elements of strategy to be unrealized. Next, we observe a positive relationship between employee support for the IT strategy and the realized IT strategy, one where a high level of employee support enables the realization of IT strategy that bears a strong resemblance to the intended IT strategy. Similarly, poorly-supported strategies will not be faithfully or fully implemented. As we noted in the prior subsection on business strategy implementation and evaluation, when deviations from intended strategies are observed, a feedback process begins. This feedback relationship enables the updating of the intended IT strategy. The feedback relationship is a negative one, indicating that a high level of agreement between the realized and intended IT strategies necessitates few changes and little additional strategic specificity in the next time period. A low level of agreement between the intended and realized IT strategies would feed back in a manner that would increase the amount of strategic change and would also promote the increasing specificity and clarity of those statements in the next time period. Finally, as in the processes of business strategy implementation, the competitive environment will likely change to lead to a shift in strategy from what was originally intended. This may be through a direct negative relationship on realized IT strategy, or indirectly as dynamism leads to the formation of emergent IT strategy which then influences the realized IT strategy. This causal loop is thus a balancing loop, incorporating both drift-inducing variables as well as a corrective feedback mechanism.

We observe here, as in the previous subsection on business strategy, that organizations may view strategic drift as beneficial in some situations and decide to allow the gap between the intended and realized IT strategies to persist. When strategic drift is viewed as potentially beneficial, the negative relationship from realized IT strategy to intended IT strategies indicates a low level of agreement and may lead to a high level of strategic change, such as when the organization's leaders work to incorporate what they have learned from the strategic experimentation, employee initiatives, or environmental opportunities in the previous period. Thus, leaders can build on valuable opportunities that they did not anticipate. 


\section{Figure 2}

IT strategy implementation and evaluation structure.

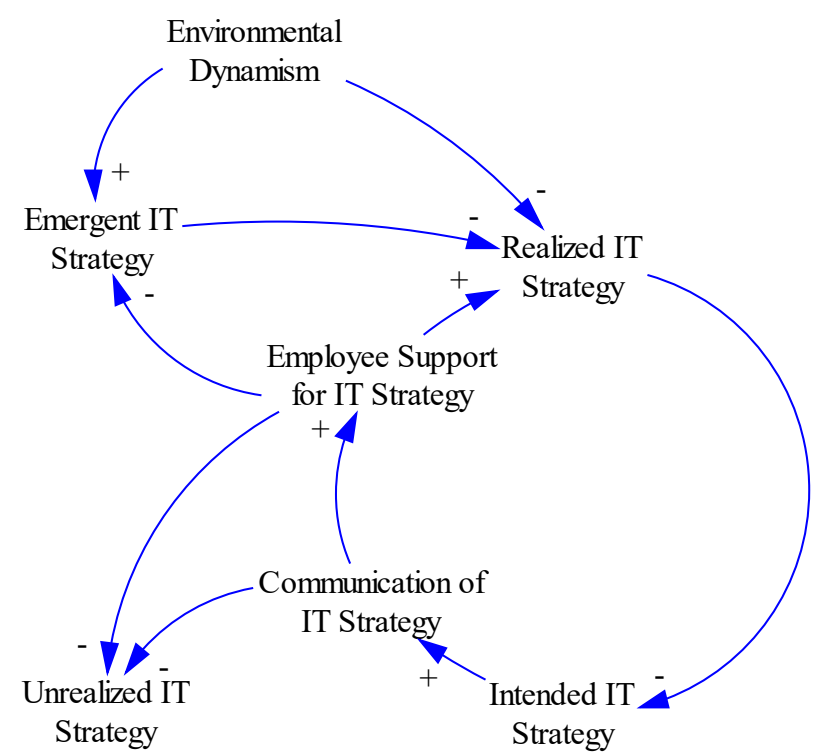

\begin{tabular}{|c|c|c|}
\hline $\begin{array}{l}\text { Causal Construct } \\
\text { definition }\end{array}$ & $\begin{array}{l}\text { Response } \\
\text { Construct }\end{array}$ & Supporting Literature \\
\hline $\begin{array}{l}\text { Intended IT Strategy } \\
\text { The plans and intentions of an organization's } \\
\text { leadership team with regard to IT, which can vary } \\
\text { in their explicitness and specificity }\end{array}$ & $\begin{array}{l}\text { Communication } \\
\text { of IT Strategy }\end{array}$ & $\begin{array}{l}\text { (Agarwal and Sambamurthy 2002; Chan et al. } \\
\text { 1997; Grover and Segars 2005; Kearns and } \\
\text { Lederer 2003; Luftman 2000; Mintzberg 1978; } \\
\text { Mintzberg and Waters 1985; Peppard and Ward } \\
\text { 2004; Sabherwal and Chan 2001; Schwarz et al. } \\
\text { 2010; Wade and Hulland 2004) }\end{array}$ \\
\hline $\begin{array}{l}\text { Communication of IT Strategy } \\
\text { Clarity of transmission of the intended IT strategy } \\
\text { from leaders to employees using written, verbal, or } \\
\text { other means }\end{array}$ & $\begin{array}{l}\text { Employee } \\
\text { Support for IT } \\
\text { Strategy }\end{array}$ & $\begin{array}{l}\text { (Chan and Huff 1992; Ciborra 2000; Gasser } \\
\text { 1986; Lapointe and Rivard 2005; Luftman 2000; } \\
\text { Markus 1983; Ravishankar et al. 2011; Rondeau } \\
\text { et al. 2006) }\end{array}$ \\
\hline Communication of IT Strategy & $\begin{array}{l}\text { Unrealized IT } \\
\text { Strategy }\end{array}$ & $\begin{array}{l}\text { (Benbya and McKelvey 2006; Ciborra 2000; } \\
\text { Luftman 2000; Mintzberg 1978; Mintzberg and } \\
\text { Waters 1985) }\end{array}$ \\
\hline $\begin{array}{l}\text { Employee Support for IT Strategy } \\
\text { Degree of acceptance, agreement, and support for } \\
\text { leadership's communicated strategic IT plans }\end{array}$ & $\begin{array}{l}\text { Unrealized IT } \\
\text { Strategy }\end{array}$ & $\begin{array}{l}\text { (Benbya and McKelvey 2006; Ciborra 2000; } \\
\text { Luftman 2000; Mintzberg 1978; Mintzberg and } \\
\text { Waters 1985) }\end{array}$ \\
\hline Employee Support for IT Strategy & $\begin{array}{l}\text { Realized IT } \\
\text { Strategy }\end{array}$ & $\begin{array}{l}\text { (Chan et al. 1997; Ciborra 2000; Gasser 1986; } \\
\text { Lapointe and Rivard 2005; Markus 1983; } \\
\text { Mintzberg 1978; Mintzberg and Waters 1985; } \\
\text { Ravishankar et al. 2011; Rondeau et al. 2006; } \\
\text { Sabherwal and Chan 2001) }\end{array}$ \\
\hline Employee Support for IT Strategy & $\begin{array}{l}\text { Emergent IT } \\
\text { Strategy }\end{array}$ & $\begin{array}{l}\text { (Benbya and McKelvey 2006; Ciborra 2000; } \\
\text { Luftman 2000; Mintzberg 1978; Mintzberg and } \\
\text { Waters 1985) }\end{array}$ \\
\hline Environmental Dynamism & Emergent IT & (Henderson and Sifonis 1988; Mintzberg 1978; \\
\hline $\begin{array}{l}\text { Rate of change in a firm's competitive environment, } \\
\text { including the rate at which consumer preferences } \\
\text { change, competitors enter the market, and new } \\
\text { technologies emerge }\end{array}$ & Strategy & Mintzberg and Waters 1985) \\
\hline Environmental Dynamism & $\begin{array}{l}\text { Realized IT } \\
\text { Strategy }\end{array}$ & $\begin{array}{l}\text { (Kearns and Lederer 2003; Sabherwal et al. } \\
\text { 2001) }\end{array}$ \\
\hline
\end{tabular}




\begin{tabular}{lll}
$\begin{array}{l}\text { Emergent IT Strategy } \\
\begin{array}{l}\text { A pattern in a stream of IT-related decisions that } \\
\text { has developed despite (or in the absence of) }\end{array}\end{array}$ & $\begin{array}{l}\text { Realized IT } \\
\text { Strategy }\end{array}$ & $\begin{array}{l}\text { (Brynjolfsson and McAfee 2014; Henderson and } \\
\text { Sifonis 1988; Mintzberg 1978; Mintzberg and } \\
\text { Waters 1985; Tanriverdi et al. 2010; Yoo et al. } \\
\text { 2010) }\end{array}$ \\
$\begin{array}{l}\text { Realized IT Strategy } \\
\begin{array}{l}\text { Actions that the organization actually took, } \\
\text { assessed as the degree of agreement with the } \\
\text { intended business strategy }\end{array}\end{array}$ & $\begin{array}{l}\text { Intended IT } \\
\text { Strategy }\end{array}$ & $\begin{array}{l}\text { (Chan et al. 1997; Sabherwal and Chan 2001; } \\
\text { Sabherwal et al. 2001) }\end{array}$ \\
\hline
\end{tabular}

The model presented in Figure 2 and the related discussion herein implies the existence of additional propositions. While propositions 1a-1d are also relevant in the context of IT strategy, here we highlight the link from research on strategic drift to IS research on user resistance as potential reasons for misalignment. Regarding the relationship from employee support for IT strategy to realized IT strategy, we propose that

Proposition 2a: Strategic drift is more likely when system usability and usefulness are low.

Proposition 2b: Strategic drift is more likely when users' political status is negatively affected by a new IS.

Regarding the relationship from emergent IT strategy to realized IT strategy, we propose that

Proposition 2c: Strategic drift is more likely when users have higher levels of IT literacy or expertise.

\subsubsection{Strategic co-evolution structure}

Another link between business and IT strategies that has been described in prior research is that of strategic co-evolution. Strategic co-evolution means that mutual adaptation takes place where IT and business capabilities develop reciprocally and iteratively over time (Agarwal and Sambamurthy 2002; Benbya and McKelvey 2006; Hirschheim and Sabherwal 2001; Peppard and Breu 2003). While historically, the IT function of an organization would adapt and develop capabilities to enable the execution of the business strategy, this lagging role for IT is no longer common or ideal. Instead, the IT function of the modern organization has the opportunity to help the firm identify and exploit IT-enabled business opportunities.

IT may continue to function in a lagging role in some organizations, providing systems and coordinating outsourcing. However, in other organizations IT facilitates agility through flexible architectures and by 
partnering with various departments for organizational transformation. In still other organizations, IT creates new strategic opportunities and thus actively leads (Guillemette and Paré 2012; Lu and Ramamurthy 2011; Overby et al. 2006). In some organizations, co-evolution will be strongly IT-influenced, while in others it will be strongly business-influenced ${ }^{4}$.

Suggested actions to stimulate co-evolution include incentivizing IT executives to experiment with new IT-enabled business models and practices, evaluating IT executives' performance in terms of strategic business drivers and metrics, and linking business executives' compensation to IT-enabled innovation (Agarwal and Sambamurthy 2002). These actions indicate that realized strategies should be assessed and used as inputs to guide future strategic development. Communication between business and IT executives can be enhanced by integrating knowledge across the two domains, by integrating business and IT strategic planning processes, and even through specific approaches in strategy articulation such as dialectical inquiry and devil's advocacy (Hirschheim and Sabherwal 2001). Indeed, feedback in the strategic implementation process enables co-evolution (Lewin and Volberda 1999), and can be understood as a form of organizational learning (van der Zee and de Jong 1999). Realized strategies that have been shaped by employees and by environmental dynamism can lead to an adaptive response where the intended strategy of the next time period is more internally consistent as well as more externally valid (Henderson and Sifonis 1988).

For these reasons, we incorporate additional feedback relationships into our model: from the realized business strategy to the intended IT strategy, and from the realized IT strategy to the intended business strategy. Figure 3 illustrates that these feedback links are negative. Where realized strategies exhibit a high degree of agreement with their corresponding intended strategies, a lower level of strategic change will be induced in the future and little additional specificity will be desired. Conversely, a low degree of agreement between intended and realized strategies would lead to a greater amount of strategic change and specificity.

\footnotetext{
${ }^{4}$ We emphasize here that the business can drive strategic change, or equally, that IT can drive strategic change. Our decision in this paper to describe the business strategy implementation process (in subsection 3.2.1) before the IT strategy implementation process (in subsection 3.2.2) is neither an explicit nor implicit statement that business strategy "leads" while IT strategy "lags".
} 


\section{Figure 3}

Strategic co-evolution structure.

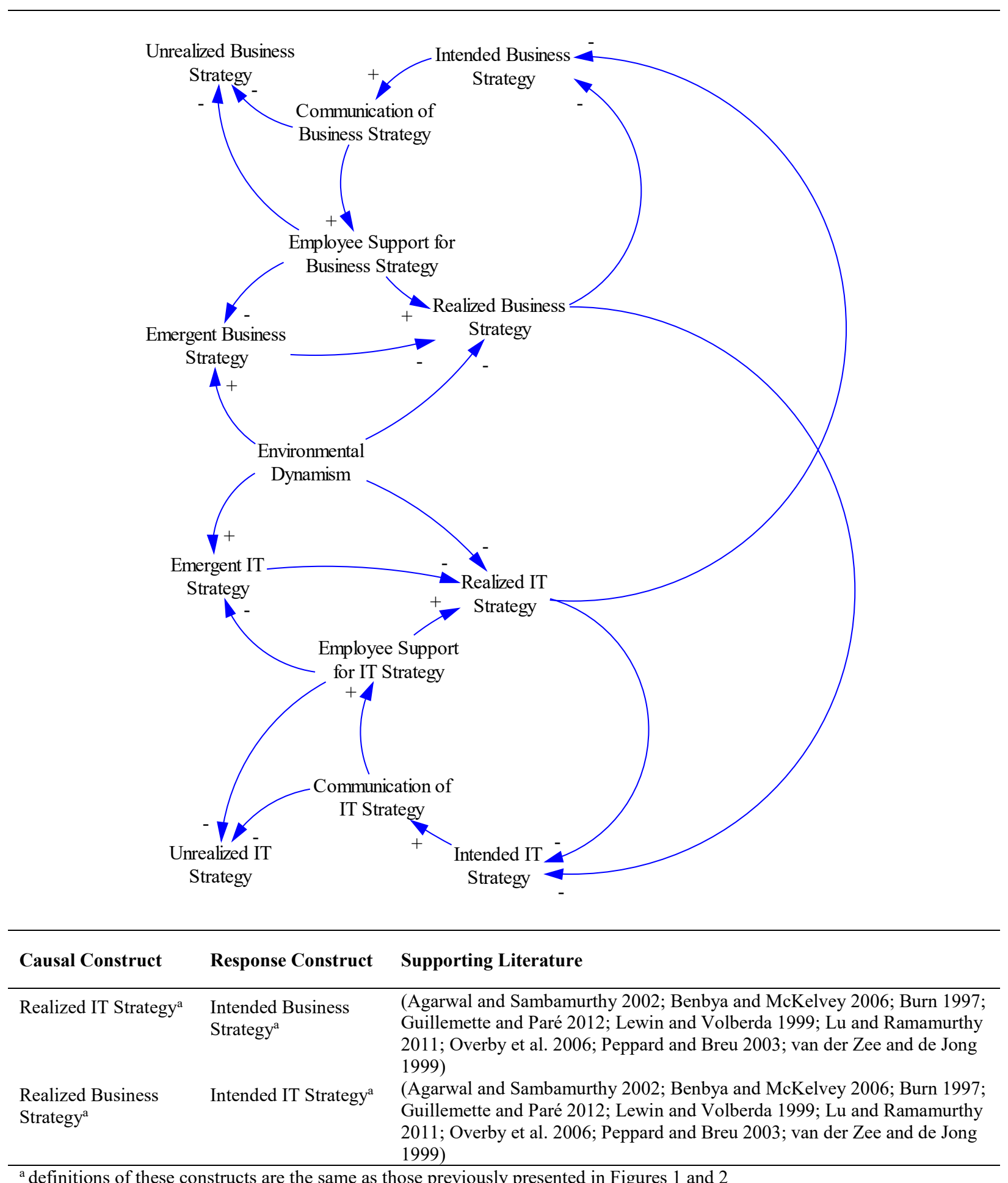

${ }^{a}$ definitions of these constructs are the same as those previously presented in Figures 1 and 2 
Examination of Figure 3 reveals additional propositions. In stable environments, firms perform better when they pursue a strategy of exploitation by focusing on obtaining more value from their existing IT products and services; in turbulent or dynamic environments, firms benefit from a strategy of exploration, where they seek to innovate and create new products and services (Xue et al. 2012). Following this logic, in settings of high environmental dynamism, strategic drift leading to feedback can be a beneficial adaptive mechanism, in the form of a strategy of exploration. In settings of low environmental dynamism, drift means that the firm is pursuing a strategy of exploration when it should be emphasizing exploitation. Finally, in settings of low environmental dynamism, strategic drift produces beneficial effects when organizational strategies do not match their environments, because drift provides the opportunity to match the strategy and the environment.

Proposition 3a: In settings of high environmental dynamism, strategic drift from an intended IT strategy can produce beneficial effects.

Proposition 3b: In settings of low environmental dynamism, strategic drift from an intended IT strategy produces deleterious (beneficial) effects when organizational strategies match (do not match) their environments.

\subsubsection{Strategic alignment structure}

Strategic alignment is consistently modeled as a function of realized business strategy and realized IT strategy (Chan et al. 1997; Sabherwal and Chan 2001; Sabherwal et al. 2001). Strategic alignment is thus an outcome of the strategy implementation process.

We observe here however, that strategic alignment also serves as an input to other constructs in the model. First, the degree of strategic alignment can be assessed and monitored (Baker et al. 2011; Gerow et al. 2014; Luftman 2000). This measurement can then be used to decide if strategic changes are necessary in either the business or IT strategies in order to maintain an existing degree of alignment or pursue a higher degree. These feedback relationships from alignment to intended strategies are illustrated in Figure 4 as negative relationships because they result in strategic adjustments rather than stasis. This negative relationship indicates that a high level of strategic alignment augurs for less strategic change going forward, while a low level of alignment promotes a higher level of strategic change and an increased emphasis on 
strategic specificity, all with the goal of improving alignment at the conclusion of the next cycle of strategic implementation.

Second, one of the most thoroughly-established relationships is the link from strategic alignment to organizational performance (Chan and Reich 2007; Gerow et al. 2014). Organizational performance has been defined and measured in various ways, including in terms of financial performance (ability to gain competitive advantage, higher profits, or stock values), productivity (improved ratio of inputs to outputs), and/or customer benefit (total benefit of a given purchase to consumers) (Gerow et al. 2014, pp. 11611162). While some variation exists in the size of the effect depending on the specific manner of measurement of the dependent variable, the relationship from alignment to organizational performance is consistently positive (Chan and Reich 2007; Gerow et al. 2014) $)^{5}$. This relationship is also illustrated in Figure 4.

Third and finally, organizational performance feeds back to the intended business strategy and intended IT strategy in the next time period. Decreases in organizational performance augur for changes in the intended business and IT strategies; rational managerial decision-making would seek strategic changes to improve performance. Thus, there is a negative relationship between organizational performance and intended business strategy. Increases in organizational performance indicate that the intended strategies are being realized with the intended effect and should presage continuity in strategic intent. At the same time, improved organizational performance can increase the financial resources available to the firm, creating new strategic possibilities for the firm. These possibilities, or strategic options, create the possibility of launching new competitive actions (Sambamurthy et al. 2003). This feedback relationship is illustrated in Figure 4, the final portion of our model.

\footnotetext{
${ }^{5}$ While the link from alignment to improved organizational performance is overwhelmingly positive in extant research (Gerow et al. 2014), in the Discussion section, we also consider situations where strategic drift and certain types of the resulting misalignment may yield beneficial outcomes.
} 
Figure 4.

Strategic Alignment Structure.

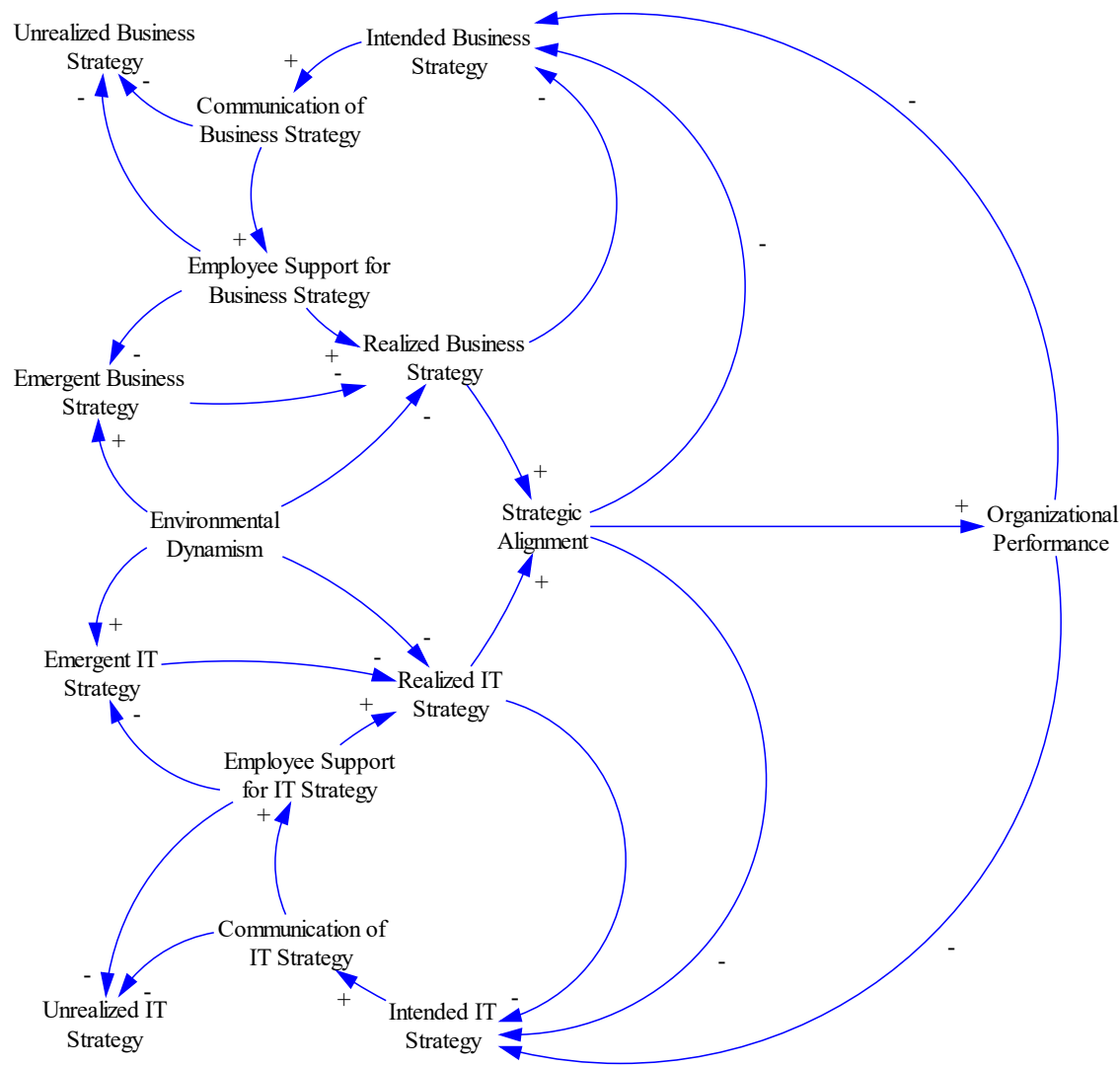

\begin{tabular}{|c|c|c|}
\hline $\begin{array}{l}\text { Causal Construct } \\
\text { definition }\end{array}$ & $\begin{array}{l}\text { Response Construct } \\
\text { definition }\end{array}$ & Supporting Literature \\
\hline Realized Business Strategy ${ }^{a}$ & Strategic Alignment & (Chan et al. 1997; Sabherwal and Chan 2001) \\
\hline Strategic Alignment & Intended Business Strategy ${ }^{a}$ & $\begin{array}{l}\text { (Chan et al. 1997; Sabherwal and Chan 2001; } \\
\text { Sabherwal et al. 2001). }\end{array}$ \\
\hline Realized IT Strategy ${ }^{a}$ & Strategic Alignment & (Chan et al. 1997; Sabherwal and Chan 2001) \\
\hline Strategic Alignment & Intended IT Strategy ${ }^{\mathrm{a}}$ & $\begin{array}{l}\text { (Chan et al. 1997; Sabherwal and Chan 2001; } \\
\text { Sabherwal et al. 2001). }\end{array}$ \\
\hline $\begin{array}{l}\text { Strategic Alignment } \\
\text { "...the degree to which the } \\
\text { information technology mission, } \\
\text { objectives, and plans support and are } \\
\text { supported by the business mission, } \\
\text { objectives, and plans" }\end{array}$ & $\begin{array}{l}\text { Organizational Performance } \\
\text { Measured in terms of } \\
\text { financial performance, } \\
\text { productivity, and/or customer } \\
\text { benefit }\end{array}$ & $\begin{array}{l}\text { (Chan et al. 1997; Chan et al. 2006; Gerow et } \\
\text { al. 2014; Hitt and Brynjolfsson 1996; Kearns } \\
\text { and Lederer 2003; Raymond and Bergeron } \\
\text { 2008; Reich and Benbasat 1996; Reich and } \\
\text { Benbasat 2000; Sabherwal and Chan 2001) }\end{array}$ \\
\hline Organizational Performance & Intended Business Strategy & (Sambamurthy et al. 2003) \\
\hline Organizational Performance & Intended IT Strategy & (Sambamurthy et al. 2003) \\
\hline
\end{tabular}

\footnotetext{
${ }^{a}$ definitions of these constructs are the same as those previously presented in Figures 1 and 2
} 
Following from Figure 4, we observe that misalignment need not always be deleterious. Indeed, in situations where IT resource deployment provides IT slack, where the firm has more IT than needed to support current business activities, performance benefits may be realized (Tallon et al. 2016). Similarly, when a realized IT strategy provides capabilities in excess of those required by the realized business strategy, this may be beneficial. In contrast, misalignment that manifests itself as a realized IT strategy that is orthogonal to the organization's realized business strategy will have a negative impact on performance; such misalignment reveals a misallocation of resources. Finally, misalignment that manifests itself as a realized IT strategy that does not provide adequate capabilities for the realized business strategy will have a negative impact on performance. Formally,

Proposition 4a: Strategic misalignment, where realized IT strategy provides capabilities in excess of those required in the intended business strategy, can yield quantifiable benefits for the organization.

Proposition 4b: Strategic misalignment, where realized IT strategy provides capabilities unrelated to those required in the intended business strategy, reduces quantifiable benefits for the organization.

Proposition 4c: Strategic misalignment, where realized IT strategy fails to provide capabilities that are adequate to meet the requirements of the business strategy, reduces quantifiable benefits for the organization.

A related issue is revealed when considering the measurement of misalignment. In the profile deviation approach, the value of a realized IT strategy is assessed by examining whether the capabilities it provides the firm match what the firm needs. In contrast, the value of a realized IT strategy can also be assessed in terms of whether it has created digital options, which are potential opportunities the firm could exploit in the future. From the digital options perspective, alignment is measured as the extent to which the IT strategy has provided a platform for creating capabilities which it might need for future iterations of its business strategy. Thus, variation from an ideal IT strategic profile may indicate the existence of digital options and be potentially valuable-it may be a positive and desirable outcome, not simply an instance of misalignment.

Proposition 4d: Misalignment measured in terms of strategic options will have a different quantifiable effect on the organization than misalignment measured as profile deviation. 


\subsubsection{Model summary}

We now present our full model, with all substructures included, as Figure 5. The relationships in the model along with their definitions and the literature that supports each definition and relationship, are provided earlier in Figures 1-4. The full complement of feedback relationships illustrated here also reveal two additional propositions:

Proposition 5a: Intended business strategy in a given time period is influenced by the realized business strategy, realized IT strategy, degree of strategic alignment, and organizational performance of previous time periods.

Proposition 5b: Intended IT strategy in a given time period is influenced by the realized business strategy, realized IT strategy, degree of strategic alignment, and organizational performance of previous time periods.

An additional, forward-looking summary of our model appears in the upcoming Discussion section, where we suggest multiple directions for future research.

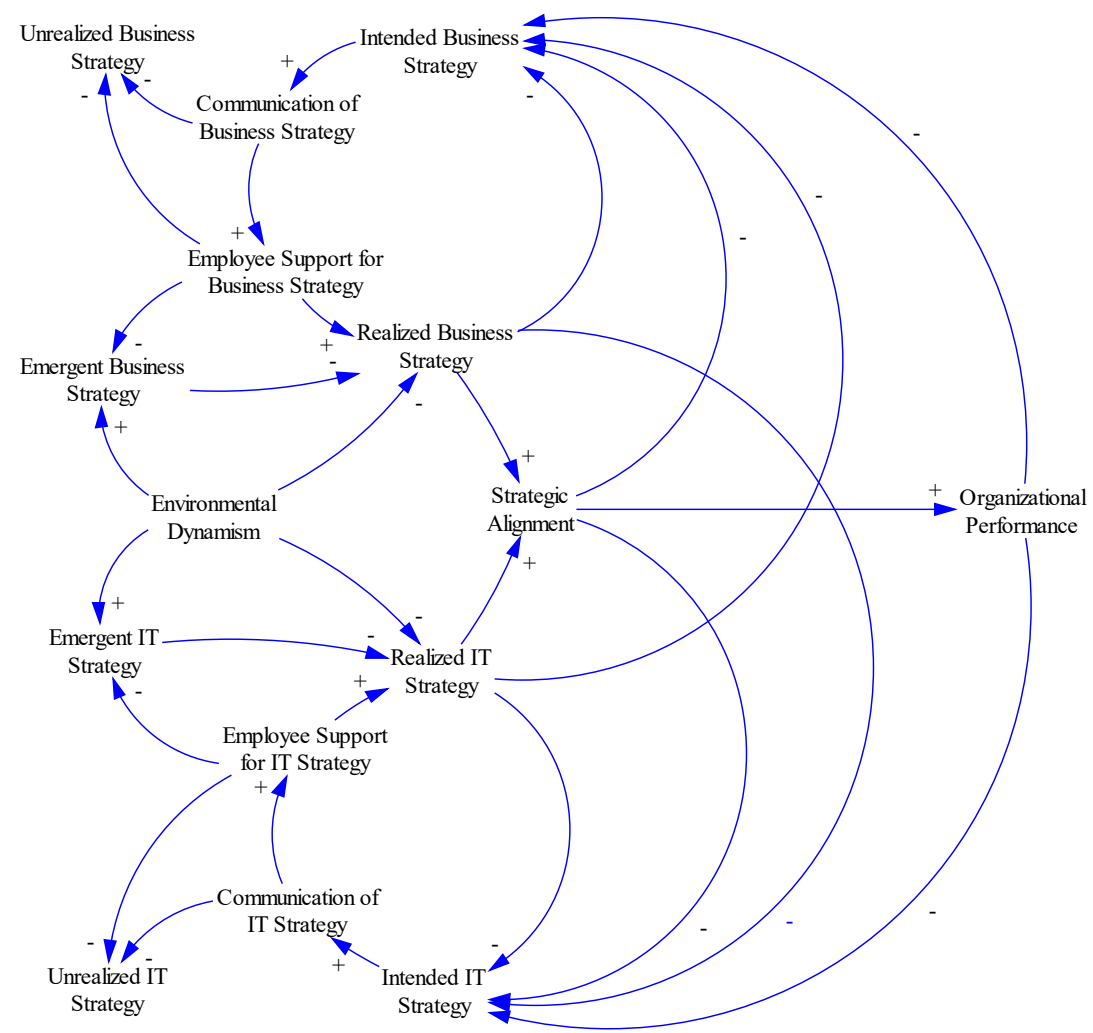

Figure 5.

Causal loop model of strategic alignment and related strategy implementation processes 


\section{Discussion}

\subsection{Theoretical implications}

The causal loop model presented here extends prior research on strategic alignment in five key ways. First, we emphasize that alignment is a product not only of exogenous variables, as is commonly assumed in factor-model-based research, but is perhaps better-understood as a product of the structure of the system of alignment-related processes within the organization. Our focus is inward, on the characteristics of the system that can lead to misalignment; and our use of causal loops represents an argument that the relevant causes of misalignment are found within a closed system, rather than outside of it. While we do not completely exclude exogenous factors such as environmental dynamism, we view them primarily as triggers of system behavior, with more substantial influence on alignment flowing from the endogenous constructs that we have identified.

The endogenous perspective is illustrated in feedback relationships, one of the primary features of our model. Such relationships exist, by definition, when information makes its way through a system and returns to its point of origin in some form (Richardson 2012), such as from an intended business strategy to a realized one, and then back again. The loops in our model highlight several reasons for misalignment and strategic change over time. More importantly though, they show that destabilizing forces are built directly into the system of alignment-related strategic implementation processes. Our emphasis on endogeneity and our description of a closed system thus represents a shift from how strategic alignment has traditionally been viewed. It indicates that sources of misalignment are paradoxically built into the structure of the system itself. We encourage continuing research that takes a systems perspective (e.g., Nan 2011; Richardson 2012; Clark et al. 2007) on strategic alignment, particularly research that examines or models the stabilizing and destabilizing elements of that system.

Second, we extend research on the dynamic capabilities framework (DCF). In the DCF, a firm's internal technological, organizational, and managerial processes enable the creation of competitive advantage (Teece et al. 1997). The majority of the constructs in this paper's model amplify deviations from the initial intended strategies. Perhaps then it is unsurprising that with so many potential stumbling blocks, alignment 
is such a challenging issue for researchers to explain and practitioners to implement. Our model reveals a set of processes that must be managed successfully if an organization is to minimize misalignment. We thus extend research on the dynamic strategic alignment competency (Baker et al. 2011; Pelletier and Raymond 2014; Schwarz et al. 2010) by identifying some of the technological, organizational, and managerial processes that provide competitive advantage through the strategic use of IT.

Third, our model indicates that the search for the causes of misalignment must be conducted in different portions of the organization than it has generally been in the past. In addition to the often-studied organizational level, investigation at the process-, group-, and individual-level is required. Strategies exist at the organizational level, but are implemented (and resisted) at the group or individual levels - and for a variety of reasons.

Our model represents the constellation of processes that influence alignment, including top-down processes such as strategic formation and the communication of strategies, and also including bottom-up processes like employee resistance that can lead to unrealized strategies, as well as to alternate emergent strategies. We link strategic management research on strategic drift and IS research on user resistance to strategic alignment as potential reasons for misalignment. Bottom-up processes with end-users playing a major role are not to be overlooked in strategic alignment research. We call for additional research focusing on the bottom of the organizational hierarchy. Middle managers and end-users represent an important but understudied population in IS research (Nan 2011). Perspectives such as agency theory and institutional theory can provide insight into problems that develop during interactions across multiple organizational levels (Eisenhardt 1988; Eisenhardt 1989), such as the communication clarity and employee buy-in elements of our model. Examining these employees and their activities will extend and emphasize the idea that alignment is indeed influenced by multilevel processes (Benbya and McKelvey 2006).

Furthermore, this paper's call for attention to the endogenous and multi-level processes of alignment, including the role of communication and feedback, point to the potential value of applying the practice perspective of strategy (Jarzabkowski et al. 2007; Whittington 2006) to study alignment. This perspective examines the specific practices used by individuals within organizations and how they lead to various 
outcomes. For example, researchers have examined how the conversational practices that intersperse formal planning activities influence the strategy that emerges (Sminia 2005). Applying a practice perspective to study alignment will enable the integration of research at the firm-, process-, and grouplevels, as well as the interaction between individuals from the IT and business units.

Fourth, and perhaps most interestingly, our model reveals ways in which even certain types of misalignment may be beneficial, as we noted in our development of propositions $1 \mathrm{c}-\mathrm{d}, 3 \mathrm{a}-\mathrm{b}$, and $4 \mathrm{a}-\mathrm{c}^{6}$. While we affirm the finding that an ideal strategic profile for the business should be matched with an ideal strategic profile for IT, and while we affirm its corollary that mismatched strategic profiles hamper organizational performance (Sabherwal and Chan 2001), misalignment may nevertheless provide value in certain settings. Our model echoes and amplifies the idea that business strategy may sometimes lead IT strategy and capabilities, and the similar idea that IT strategy may sometimes lead the business's strategy and capabilities (Guillemette and Paré 2012; Itami and Numagami 1992), both of which are forms of misalignment. This type of misalignment opens the door for feedback during the next time period, from realized strategies to the next time period's intended strategies. Perfect alignment would reduce the need for and the value gained from feedback. New strategic initiatives may be identified and pursued in the next time period precisely because of recognized misalignment.

Others have similarly noted that when the realized IT strategy provides capabilities that go beyond the business's current needs, IT business value is created (Jarvenpaa and Ives 1993; Tallon et al. 2016). This form of misalignment, where value is built as agility and strategic options are created through slack IT resources, is also a potentially beneficial form of misalignment.

We extend this prior work to note that perfect alignment could be understood as intended strategies that are realized exactly as intended, and using only the technology available at the time the intended strategy is formulated. In contrast, if technology were to function in a leading role, creating strategic opportunities before they are formally incorporated into an intended business strategy, this is a type of misalignment, but

\footnotetext{
${ }^{6} \mathrm{We}$ are grateful to an anonymous reviewer for helping to shape our thinking on this issue.
} 
a potentially beneficial one. Technology in a leading role may represent IT slack and provides the organization with strategic options for the future. Similarly, when business strategy functions in a leading role, with IT strategy lagging behind, this is a form of misalignment; but if it leads to expansion, growth, or renewal of the IT function following feedback, the observation of misalignment can be beneficial. The IT strategy will be revised to enable the execution of the intended business strategy in subsequent time periods.

Additionally, we note that the general state of technological maturity in an industry may influence whether an organization wants its intended IT strategy to lead, lag, or be matched with its intended business strategy. As corollary statements to our propositions $4 \mathrm{a}, 4 \mathrm{~b}$, and $4 \mathrm{c}$ regarding beneficial types of misalignment, we suggest that in industries with mature technologies and stable rates of growth, alignment through closely-matched strategies would be ideal. If misalignment exists in such industries, the better form of it would be where business strategy leads technology, which would have the effect of clearly focusing technological initiatives for cost control and efficiency. In high-growth industries, or where technologies are not yet mature, we propose that IT in a leading role would be more beneficial as it promotes agility and creates potentially valuable strategic options for the organization.

Fifth and finally, we invite refinement of the definition of strategic alignment. The currently accepted definitions include "...the degree to which the information technology mission, objectives, and plans support and are supported by the business mission, objectives, and plans" (Reich and Benbasat 2000, p. 82) and the highly similar "the degree to which the mission, objectives, and plans contained in the business strategy are shared and supported by the IS strategy" (Chan et al. 2006, p. 27), both of which are utilized in recent meta-analyses and literature reviews (Gerow et al. 2015; Gerow et al. 2014). We observe a slight inconsistency where these definitions emphasize alignment between "plans", but related research measures "realized" strategies (e.g., Chan et al., 1997, p. 126; Sabherwal and Chan 2001, p. 13). Perhaps a distinction 
could be made between the state of intended alignment - and the state of realized alignment, a distinction that would bring a helpful degree of specificity to future alignment research ${ }^{7}$.

The aforementioned suggestions for future research should be undertaken using a variety of methodological approaches - including mathematical simulation, surveys, interviews, content analysis of executives' strategic statements, focus groups with employees and executives, and interpretive case studies - in order to provide a comprehensive understanding of strategic alignment and robust findings.

\subsection{Practical implications}

Practitioners seeking to avoid misalignment should consider ways in which they can manage strategic drift. Drift can be managed through both formal as well as informal controls. Both types of controls should be utilized as governance is achieved through both control and collaboration (Sundaramurthy and Lewis 2003). For instance, with IT strategies, rigorously-codified IS governance frameworks, such as COBIT (Control Objectives for IT) and ITIL (IT Infrastructure Library) may be helpful. These are auditable lists of processes that organizations are recommended to implement, so that their IT systems and services remain usable and useful, as well as aligned with their business. The ITIL framework outlines a series of processes to help managers use the firm's strategy statements to identify key business relationships, estimate demand for IT services from internal users and external value chain partners, and design a cost-effective portfolio of IT services. These frameworks are intended to develop a culture of market-responsive IT and continual IT service improvement. Similarly, some of the key enabling processes in COBIT 5, such as EDM05 (“enabling stakeholder transparency"), APO02 (“manage strategy") and BAI05 ("manage organizational change enablement"), outline the communication and reporting practices organizations should adopt, and the corresponding metrics that should be monitored to achieve enterprise and IT-related goals.

Such guidelines can assist with the formation, explication, and communication of strategies, and can also help identify areas in which systems are not meeting users' expectations, alerting management to potential areas where strategy may be modified by middle managers and end users. Additionally, senior

\footnotetext{
${ }^{7}$ We are grateful to an anonymous reviewer, whose comments and suggestions regarding prior literature led us to this observation.
} 
managers may wish to implement procedures whereby middle managers are substantively involved in the strategy formation process. Such procedures have the effect of improving communication, monitoring middle managers' as well as their direct reports' commitment to a strategic initiative, and gauging social or political motivations for resistance (Huy 2011; Sharma and Yetton 2003; Wooldridge and Floyd 1990).

Firms operating in environments with high levels of uncertainty may sometimes use rolling planning forecasts or planning horizons that extend incrementally every year or every quarter to manage the ambiguity in their markets (Granlund and Taipaleenmäki 2005). In such contexts, strategic plans are used more for coordinating activities and managing performance, instead of making specific decisions (Grant 2003). Organizations that have rigid planning horizons may find it difficult to change their goals so that they can take advantage of potential opportunities or avoid dangers (Das 1991). On the other hand, planning flexibility supports innovativeness and firm performance (Dibrell et al. 2014). Thus, firms that have longer planning cycles will find it more difficult to adapt, suggesting that drift would be more beneficial for them than firms with shorter planning cycles.

Informal controls, while less-commonly discussed, should not be overlooked in managing drift and misalignment. Researchers have argued that informal or implicit control systems, based on shared norms, can be more effective for achieving coordination than formal control systems that depend on explicit rules and regulations (Denison and Mishra 1995; Ouchi 1979). In the IT department, informal structures play a much more important role in improving IS performance than formal structures (Chan 2002). Instead of relying on strict controls to enforce the use of official systems, well-developed personal relationships may be more effective at preventing workarounds or the use of shadow systems. Although informal governance has been said to be unrepeatable and ad-hoc (Boh and Yellin 2007), its value lies in the shared understandings it creates in the working environment. Managers will no doubt also want to assess the effectiveness of each of these aforementioned drift-management procedures.

Practitioners in high-growth and innovation-focused industries should also note that deviation from intended strategies can at times have beneficial effects. Organizations with an entrepreneurial orientation create value and gain competitive advantage by combining resources in a novel way to take advantage of 
opportunities in the environment, often resulting in new ventures, products, services, processes, and technologies (Morris 1998). In IS/IT research, it has been noted that one of the keys to successful entrepreneurship is improvisation, which is "the ability to spontaneously reconfigure existing resources to build new operational capabilities to address urgent, unpredictable, and novel environmental situations" (Pavlou and El Sawy, 2010, p. 443). Organizations that have an entrepreneurial culture choose to closely watch and quickly respond to changes in the competitive environment. Rather than committing to an inflexible strategy, entrepreneurial firms have the outlook that enables the creation of valuable strategic options (Raynor 2007). Rather than simply observing, or even guarding against changes in market conditions, they build flexible organizations that respond rapidly. Such organizations may be more willing to embrace emergent strategies. Practitioners in such settings need not fear losing the ability to achieve alignment, as even the most flexible and readily-changeable entrepreneurial organization types have been observed as being capable of high levels of strategic alignment (Street et al. 2017). Nevertheless, practitioners should carefully consider the potential benefit that innovation and experimentation offer, even though they may lead to a temporary misalignment.

Similarly, the IT department can suggest innovative (but non-standard and non-authorized) technologies to launch discussions within the firm about device and system choice, and about the needs of employees (Twentyman 2011). The IT function can capitalize on these opportunities for experimentation to burnish its image as responsive, proactive, and enabling. Overall, senior managers are advised to consider ways they can encourage and reward experimentation and innovation by middle managers and end-users, effectively crowd-sourcing emergent ideas from within the firm, with the ultimate goal of enhancing organizational capabilities through IT.

\section{Conclusion}

In spite of decades of research into strategic alignment, it remains an elusive goal and a major cause for concern among practitioners. Achieving a high degree of alignment over time is challenging not only because it involves numerous processes and sub-processes, but also because it involves various stakeholders 
in multiple departments and at multiple levels of the organization. While factor models have presented specific conclusions and actionable insights, the analysis here presents a more nuanced picture, one of strategic alignment as a complex, nonlinear system with interactions, feedback, and circular causality in the midst of a dynamic competitive environment.

Our perspective enriches existing research by identifying not only the factors, but also the processes, routines, and sequences that shape alignment, focusing on the "what" of alignment as well as the "how". Strategic drift, feedback relationships, and strategic co-evolution all represent ways in which misalignment can occur. These ideas have the potential to reshape the way in which strategic alignment is discussed and investigated, because they imply that, besides alignment itself, the strategy formulation and governance processes that promote alignment, and the strategic drift that retards and prevents alignment, should be studied as well. We see models such as this one as increasingly valuable in the current era of shorter planning cycles, increasing market dynamism, and hypercompetition. We hope that this paper will encourage others to continue this process of reformulation and rediscovery.

\section{References}

Agarwal, R., and Sambamurthy, V. 2002. "Principles and Models for Organizing the IT Function," MIS Quarterly Executive (1:1), pp. 1-16.

Azoulay, P., Repenning, N. P., and Zuckerman, E. W. 2010. "Nasty, Brutish, and Short: Embeddedness Failure in the Pharmaceutical Industry," Administrative Science Quarterly (55:3), pp. 472-507.

Baets, W. J. 1992. "Aligning Information Systems with Business Strategy," Journal of Strategic Information Systems (1:4), pp. 205-213.

Baker, J., Jones, D., Cao, Q., and Song, J. 2011. "Conceputualizing the Dynamic Strategic Alignment Competency," Journal of the Association for Information Systems (12:4, article 2).

Balogun, J. 2006. "Managing Change: Steering a Course between Intended Strategies and Unanticipated Outcomes," Long Range Planning (39:1), pp. 29-49.

Balogun, J., and Johnson, G. 2005. "From Intended Strategies to Unintended Outcomes: The Impact of Change Recipient Sensemaking," Organization Studies (26:11), pp. 1573-1601.

Benbya, H., and McKelvey, B. 2006. "Using Coevolutionary and Complexity Theories to Improve Is Alignment: A Multilevel Approach," Journal of Information Technology (21:4), pp. 284-298.

Bergstein, B. 2012. "IBM Faces the Perils Of "Bring Your Own Device"," in: MIT Technology Review.

Bharadwaj, A., El Sawy, O. A., Pavlou, P. A., and Venkatraman, N. 2013. "Digital Business Strategy: Toward a Next Generation of Insights," MIS Quarterly (37:2), pp. 471-482.

Bhattacherjee, A., and Premkumar, G. 2004. "Understanding Changes in Belief and Attitude Towards Information Technology Usage: A Theoretical Model and Longitudinal Test," MIS Quarterly (28:2), pp. 229-254.

Black, L. J., Carlile, P. R., and Repenning, N. P. 2004. "A Dynamic Theory of Expertise and Occupational Boundaries in New Technology Implementation: Building on Barley's Study of CTt Scanning," Administrative Science Quarterly (49:4), pp. 572-607. 
Boh, W., and Yellin, D. 2007. "Using Enterprise Architecture Standards in Managing Information Technology," Journal of Management Information Systems (23:3), pp. 163-207.

Brynjolfsson, E., and McAfee, A. 2014. The Second Machine Age: Work, Progress, and Prosperity in a Time of Brilliant Technologies. New York, New York: W. W. Norton \& Company.

Burn, J. M. 1997. "A Professional Balancing Act - Walking the Tightrope of Strategic Alignment," in Steps to the Future - Fresh Thinking on the Management of It-Based Organizational Transformation, C. Sauer and P.W. Yetton (eds.). San Francisco: Jossey-Bass Publishers, pp. 55-88.

Campbell, B., Kay, R., and Avison, D. 2005. "Strategic Alignment: a Practitioner's Perspective," Journal of Enterprise Information Management (18:6), pp. 653-664.

Chan, Y. E. 2002. "Why Haven't We Mastered Alignment? The Importance of the Informal Organizational Structure," MIS Quarterly Executive (1:2), pp. 97-112.

Chan, Y. E., and Huff, S. L. 1992. "Strategy: An Information Systems Research Perspective," Journal of Strategic Information Systems (1:14), pp. 191-204.

Chan, Y. E., Huff, S. L., Barclay, D. W., and Copeland, D. G. 1997. "Business Strategic Orientation, Information Systems Strategic Orientation, and Strategic Alignment," Information Systems Research (8:2), pp. 125-150.

Chan, Y. E., and Reich, B. H. 2007. "IT Alignment: What Have We Learned?," Journal of Information Technology (22:6), pp. 297-315.

Chan, Y. E., Sabherwal, R., and Thatcher, J. B. 2006. "Antecedents and Outcomes of Strategic IS Alignment: An Empirical Investigation," IEEE Transactions on Engineering Management (51:3), pp. 27-47.

Choi, J., Nazareth, D. L., and Jain, H. K. 2010. "Implementing Service-Oriented Architecture in Organizations," Journal of Management Information Systems (26:4), pp. 253-286.

Ciborra, C. 2000. From Control to Drift: The Dynamics of Corporate Information Infrastructures. Oxford, UK: Oxford University Press.

Ciborra, C. U. 1997. "De Profundis? Deconstructing the Concept of Strategic Alignment," Scandinavian Journal of Information Systems (9:1), pp. 67-82.

Clark, T. D., Jones, M. C., and Armstrong, C. P. 2007. "The Dynamic Structure of Management Support Systems: Theory Development, Research Focus, and Direction," MIS Quarterly (31:3), pp. 579615.

Coltman, T., Sharma, R., Tallon, P., and Queiroz, M. 2015. "Strategic IT Alignment: Twenty-Five Years On," Journal of Information Technology (30:2), pp. 91-100.

Cyert, R. M., and March, J. G. 1963. A Behavioral Theory of the Firm. Englewood Cliffs, NJ: PrenticeHall.

Das, T. 1991. "Time: The Hidden Dimension in Strategic Planning," Long Range Planning (24:3), pp. 4957.

Denison, D. R., and Mishra, A. K. 1995. "Toward a Theory of Organizational Culture and Effectiveness," Organization Science (6:2), pp. 204-223.

Dibrell, C., Craig, J. B., and Neubaum, D. O. 2014. "Linking the Formal Strategic Planning Process, Planning Flexibility, and Innovativeness to Firm Performance," Journal of Business Research (67:9), pp. 2000-2007.

Dierickx, I., and Cool, K. 1989. "Asset Stock Accumulation and Sustainability of Competitive Advantage," Management Science (35:12), pp. 1504-1511.

Druckenmiller, D. A., and Acar, W. 2009. "An Agent-Based Collaborative Approach to Graphing Causal Maps for Situation Formulation," Journal of the Association for Information Systems (10:3), pp. 221-251.

Dutta, A. 2001. "Business Planning for Network Services: A Systems Thinking Approach," Information Systems Research (12:3), pp. 260-283.

Dutta, A., and Roy, R. 2005. "Offshore Outsourcing: a Dynamic Causal Model of Counteracting Forces," Journal of Management Information Systems (22:2), pp. 15-35. 
Dutton, J. E., and Ashford, S. J. 1993. "Selling Issues to Top Management," Academy of Management Review (18:3), pp. 397-428.

Dutton, J. E., Ashford, S. J., O'Neill, R. M., and Lawrence, K. A. 2001. "Moves That Matter: Issue Selling and Organizational Change," Academy of Management Journal (44:4), pp. 716-736.

Eisenhardt, K. 1988. "Agency- and Institutional-Theory Explanations: the Case of Retail Sales Compensation," Academy of Management Journal (31:3), pp. 488-511.

Eisenhardt, K., and Tabrizi, E. 1995. "Accelerating Adaptive Processes: Product Innovation in the Global Computer Industry," Administrative Science Quarterly (40:1), pp. 85-110.

Eisenhardt, M., K. 1989. "Agency Theory: An Assessment and Review," Academy of Management Review (14:1), p. 57.

Fang, Y., Lim, K. H., Qian, Y., and Feng, B. 2018. "System Dynamics Modeling for Information Systems Research: Theory Development and Practical Application," MIS Quarterly (42:4).

Forrester, J. W. 1961. Industrial Dynamics. Cambridge, MA: The MIT Press.

Gasser, L. 1986. "The Integration of Computing and Routine Work," ACM Transactions on Information Systems (4:3), pp. 205-225.

Gerow, J. E., Thatcher, J. B., and Grover, V. 2015. "Six Types of IT-Business Strategic Alignment: An Investigation of the Constructs and Their Measurement," European Journal of Information Systems (24:2).

Gerow, J. E., Thatcher, J. B., Grover, V., and Roth, P. L. 2014. "Looking toward the Future of IT-Business Strategic Alignment through the Past: A Meta-Analysis," MIS Quarterly (38:4), pp. 1059-1085.

Granlund, M., and Taipaleenmäki, J. 2005. "Management Control and Controllership in New Economy Firms - a Life Cycle Perspective," Management Accounting Research (16:1), pp. 21-57.

Grant, R. M. 2003. "Strategic Planning in a Turbulent Environment: Evidence from the Oil Majors," Strategic Management Journal (24:6), pp. 491-517.

Grover, V., and Segars, A. H. 2005. "An Empirical Evaluation of Stages of Strategic Information Systems Planning: Patterns of Process Design and Effectiveness," Information \& Management (42:5), pp. 761-779.

Guillemette, M. G., and Paré, G. 2012. "Toward a New Theory of the Contribution of the IT Function in Organizations," MIS Quarterly (36:2), pp. 529-551.

Gupta, Y. P., Karimi, J., and Somers, T. M. 1997. "Alignment of a Firm's Competitive Strategy and Information Technology Management Sophistication: The Missing Link," IEEE Transactions on Engineering Management (44:4), pp. 399-413.

Helfat, C. E., Finkelstein, S., Mitchell, W., Peteraf, M., Singh, H., Teece, D., and Winter, S. G. 2009. Dynamic Capabilities: Understanding Strategic Change in Organizations. John Wiley \& Sons.

Henderson, J. C., and Sifonis, J. G. 1988. "The Value of Strategic IS Planning: Understanding Consistency, Validity, and Is Markets," MIS quarterly (12:2), pp. 187-200.

Hirschheim, R., and Sabherwal, R. 2001. "Detours in the Path toward Strategic Information Systems Alignment," California Management Review (44:1), pp. 87-108.

Hitt, L. M., and Brynjolfsson, E. 1996. "Productivity, Business Profitability, and Consumer Surplus: Three Different Measures of Information Technology Value," MIS Quarterly (20:2), p. 121.

Hsiao, R. L., and Ormerod, R. J. 1998. "A New Perspective on the Dynamics of Information TechnologyEnabled Strategic Change," Information Systems Journal (8:1), pp. 21-52.

Huy, Q. N. 2011. "How Middle Managers' Group-Focus Emotions and Social Identities Influence Strategy Implementation," Strategic Management Journal (32:13), pp. 1387-1410.

Ireland, R. D., Hitt, M. A., and Sirmon, D. G. 2003. "A Model of Strategic Entrepreneurship: The Construct and Its Dimensions," Journal of Management (29:6), pp. 963-989.

Itami, H., and Numagami, T. 1992. "Dynamic Interaction between Strategy and Technology," Strategic Management Journal (13:S2), pp. 119-135.

Jarvenpaa, S. L., and Ives, B. 1993. "Organizing for Global Competition: The Fit of Information Technology," Decision Sciences (24:3), pp. 547-580. 
Jarzabkowski, P., Balogun, J., and Seidl, D. 2007. "Strategizing: The Challenges of a Practice Perspective," Human Relations (60:1), pp. 5-27.

Jarzabkowski, P., and Sillince, J. 2007. "A Rhetoric-in-Context Approach to Building Commitment to Multiple Strategic Goals," Organization Studies (28:11), pp. 1639-1665.

Kaneshige, T. 2010. "Seven Steps to Stronger Enterprise Iphone Security," CIO (August 3, 2010).

Kappelman, L., Torres, R., McLean, E., Maurer, C., Johnson, V., and Kim, K. 2019. "The 2018 Sim IT Issues and Trends Study," MIS Quarterly Executive (18:1), p. Article 7.

Karpovsky, A., and Galliers, R. 2015. "Aligning in Practice: From Current Cases to a New Agenda," Journal of Information Technology (30), pp. 1-25.

Kearns, G. S., and Lederer, A. L. 2003. "A Resource-Based View of Strategic IT Alignment: How Knowledge Sharing Creates Competitive Advantage," Decision Sciences (34:1), pp. 1-29.

King, A. W., and Zeithaml, C. P. 2001. "Competencies and Firm Performance: Examining the Causal Ambiguity Paradox," Strategic Management Journal (22:1), pp. 75-99.

Kirzner, I. M. 1973. Competition and Entrepreneurship. Chicago: University of Chicago Press.

Klein, K. J., and Kozlowski, S. W. 2000a. "From Micro to Meso: Critical Steps in Conceptualizing and Conducting Multilevel Research," Organizational Research Methods (3:3), pp. 211-236.

Klein, K. J., and Kozlowski, S. W. 2000b. Multilevel Theory, Research, and Methods in Organizations: Foundations, Extensions, and New Directions. Jossey-Bass.

Lapointe, L., and Rivard, S. 2005. "A Multilevel Model of Resistance to Information Technology Implementation," MIS Quarterly (29:3), pp. 461-491.

Leidner, D., Milovich, M., and Preston, D. 2017. "Rethinking IS Strategic Alignment: A Middle Management Perspective," International Conference on Information Systems 2017.

Lewin, A. Y., and Volberda, H. W. 1999. "Coevolution of Strategy and New Organizational Forms," Organization Science (10:5), pp. 519-534.

Lewis, L. K. 2007. "An Organizational Stakeholder Model of Change Implementation Communication," Communication Theory (17:2), pp. 176-204.

Li, X., and Madnick, S. E. 2015. "Understanding the Dynamics of Service-Oriented Architecture Implementation," Journal of Management Information Systems (32:2), pp. 104-133.

Lu, Y., and Ramamurthy, K. 2011. "Understanding the Link between Information Technology Capability and Organizational Agility: An Empirical Examination," MIS Quarterly (35:4), pp. 931-954.

Luftman, J. 2000. "Assessing Business-IT Alignment Maturity," Communications of the AIS (4:14), pp. 150.

Markus, M. L. 1983. "Power, Politics, and MIS Implementation," Communications of the ACM (26:6), pp. 430-444.

Martin, A. 2008. "Digital Literacy and the "Digital Society"," Digital literacies: Concepts, policies and practices (30), pp. 151-176.

Messmer, E. 2013. "London Gatwick Airport Takes out 200 Servers, Moves to Cloud, BYOD," in: Network World.

Mintzberg, H. 1978. "Patterns in Strategy Formulation," Management Science (24:9), pp. 934-948.

Mintzberg, H., and Waters, J. A. 1985. "Of Strategies, Deliberate and Emergent," Strategic Management Journal (6:3), pp. 257-272.

Morris, M. H. 1998. Entrepreneurial Intensity: Sustainable Advantages for Individuals, Organizations, and Societies. Praeger.

Nan, N. 2011. "Capturing Bottom-up Information Technology Use Processes: a Complex Adaptive Systems Model," MIS Quarterly (35:2), pp. 505-532.

Newkirk, H. E., and Lederer, A. L. 2006. "The Effectiveness of Strategic Information Systems Planning under Environmental Uncertainty," Information \& Management (43:4), pp. 481-501.

Orlikowski, W. J., and Scott, S. V. 2008. "Sociomateriality: Challenging the Separation of Technology, Work and Organization," The Academy of Management Annals (2:1), pp. 433-474.

Ouchi, W. G. 1979. "A Conceptual Framework for the Design of Organizational Control Mechanisms," Management Science (25:9), pp. 833-848. 
Overby, E., Bharadwaj, A., and Sambamurthy, V. 2006. "Enterprise Agility and the Enabling Role of Information Technology," European Journal of Information Systems (15:2), pp. 120-131.

Pelletier, C., and Raymond, L. 2014. "The IT Strategic Alignment Process: a Dynamic Capabilities Conceptualization," Americas Conference on Information Systems (AMCIS) 2014, Savannah, GA, USA, p. Poster 7.

Peppard, J., and Breu, K. 2003. "Beyond Alignment: A Coevolutionary View of the Information Systems Strategy Process," Proceedings of the 24th International Conference on Information Systems, pp. 743-750.

Peppard, J., and Ward, J. 2004. "Beyond Strategic Information Systems: Towards an IS Capability," The Journal of Strategic Information Systems (13:2), pp. 167-194.

Perlow, L. A., Okhuysen, G. A., and Repenning, N. P. 2002. "The Speed Trap: Exploring the Relatikonship between Decision Making and Temporal Context," Academy of Management Journal (45:5), pp. 931-955.

Piccoli, G., and Ives, B. 2005. "Review: IT-Dependent Strategic Initiatives and Sustained Competitive Advantage: A Review and Synthesis of the Literature," MIS Quarterly (29:4), pp. 747-776.

Powell, T. C. 1992. "Organizatonal Alignment as Competitive Advantage," Strategic Management Journal (13:2), pp. 119-134.

Preston, D. S., and Karahanna, E. 2009. "Antecedents of IS Strategic Alignment: A Nomological Network," Information Systems Research (20:2), pp. 159-179.

Raes, A. M., Heijltjes, M. G., Glunk, U., and Roe, R. A. 2011. "The Interface of the Top Management Team and Middle Managers: A Process Model," Academy of Management Review (36:1), pp. 102-126.

Rau, K. G. 2004. "Effective Governance of It: Design Objectives, Roles, and Relationships," Information Systems Management (21:4), pp. 35-42.

Ravishankar, M., Pan, S. L., and Leidner, D. E. 2011. "Examining the Strategic Alignment and Implementation Success of a KMS: A Subculture-Based Multilevel Analysis," Information Systems Research (22:1), pp. 39-59.

Raymond, L., and Bergeron, F. 2008. "Enabling the Business Strategy of SMEs through E-Business Capabilities: A Strategic Alignment Perspective," Industrial Management \& Data Systems (108:5), pp. 577-595.

Raynor, M. E. 2007. The Strategy Paradox: Why Committing to Success Leads to Failure (and What to Do About It). Crown Business.

Reich, B. H., and Benbasat, I. 1996. "Measuring the Linkage between Business and Information Technology Objectives," MIS Quarterly (20:1), pp. 55-81.

Reich, B. H., and Benbasat, I. 2000. "Factors That Influence the Social Dimension of Alignment between Business and IT Objectives," MIS Quarterly (24:1), pp. 81-113.

Repenning, N. P., and Sterman, J. D. 2002. "Capability Traps and Self-Confirming Attribution Errors in the Dynamics of Process Improvement," Administrative Science Quarterly (47:2), pp. 265-295.

Richardson, G. P. 2012. "System Dynamics," in Encyclopedia of Operations Research and Management Science, S.I. Gass and C.M. Harris (eds.). Springer Science \& Business Media.

Rondeau, P. J., Ragu-Nathan, T., and Vonderembse, M. A. 2006. "How Involvement, IS Management Effectiveness, and End-User Computing Impact IS Performance in Manufacturing Firms," Information \& Management (43:1), pp. 93-107.

Rudolph, J. W., and Repenning, N. P. 2002. "Disaster Dynamics: Understanding the Role of Quantity in Organizational Collapse," Administrative Science Quarterly (47:1), pp. 1-30.

Sabherwal, R., and Chan, Y. E. 2001. "Alignment between Business and IS Strategies: A Study of Prospectors, Analyzers, and Defenders," Information Systems Research (12:1), p. 11.

Sabherwal, R., Hirschheim, R., and Goles, T. 2001. "The Dynamics of Alignment: Insights from a Punctuated Equilibrium Model," Organization Science (12:2), pp. 179-197.

Sambamurthy, V., Bharadwaj, A., and Grover, V. 2003. "Shaping Agility through Digital Options: Reconceptualizing the Role of Information Technology in Contemporary Firms," MIS Quarterly (27:2), pp. 237-263. 
Schwarz, A., Kalika, M., Kefi, H., and Schwarz, C. 2010. "A Dynamic Capabilities Approach to Understanding the Impact of It-Enabled Businesses Processes and IT-Business Alignment on the Strategic and Operational Performance of the Firm," Communications of the AIS (26:4), pp. 57-84.

Shane, S., and Venkataraman, S. 2000. "The Promise of Enterpreneurship as a Field of Research," Academy of Management Review (25:1), pp. 217-226.

Sharma, R., and Yetton, P. 2003. "The Contingent Effects of Management Support and Task Interdependence on Successful Information Systems Implementation," MIS Quarterly (27:4), pp. 533-555.

Singh, H. 2015. "Emergence and Consequences of Drift in Organizational Information Systems," PACIS 2015, p. Paper 202.

Sledgianowski, D., and Luftman, J. 2005. "IT-Business Strategic Alignment Maturity: A Case Study," Journal of Cases on Information Technology (7:2), pp. 102-120.

Sminia, H. 2005. "Strategy Formation as Layered Discussion," Scandinavian Journal of Management (21:3), pp. 267-291.

Stewart, M. 2009. "Obama to Get Spy-Proof Smartphone," in: CNN.com. p. http://edition.cnn.com/2009/POLITICS/2001/2022/obama.blackberry/.

Street, C., Gallupe, B., and Baker, J. 2017. "The Influence of Entrepreneurial Action on Strategic Alignment in New Ventures: Searching for the Genesis of Alignment," The Journal of Strategic Information Systems (27:1), pp. 59-81.

Street, C. T. 2006. "Evolution in IS Alignment and IS Alignment Capabilities over Time: A Test of Punctuated Equilibrium Theory." Unpublished Doctoral Dissertation, Queen's University.

Sundaramurthy, C., and Lewis, M. 2003. "Control and Collaboration: Paradoxes of Governance," The Academy of Management Review (28:3), pp. 397-415.

Sutanto, J., Kankanhalli, A., Tay, J., Raman, K. S., and Tan, B. C. Y. 2008-9. "Change Management in Interorganizational Systems for the Public," Journal of Management Information Systems (25:3), pp. 133-175.

Tallon, P. P. 2007. "A Process-Oriented Perspective on the Alignment of Information Technology and Business Strategy," Journal of Management Information Systems (24:3), pp. 227-268.

Tallon, P. P. 2011. "Value Chain Linkages and the Spillover Effects of Strategic Information Technology Alignment: A Process-Level View," Journal of Management Information Systems (28:3), pp. 9-44.

Tallon, P. P., Coltman, T., Queiroz, M., and Sharma, R. 2016. "Business Process and Information Technology Alignment: Construct Conceptualization, Empirical Illustration, and Directions for Future Research," Journal of the Association for Information Systems (17:9), p. 563.

Tallon, P. P., and Pinsonneault, A. 2011. "Competing Perspectives on the Link between Strategic Information Technology Alignment and Organizational Agility: Insights from a Mediation Model," MIS Quarterly (35:2), pp. 463-486.

Tanriverdi, H., Rai, A., and Venkatraman, N. 2010. "Research Commentary: Reframing the Dominant Quests of Information Systems Strategy Research for Complex Adaptive Business Systems," Information Systems Research (21:4), pp. 822-834.

Tarafdar, M., and Qrunfleh, S. 2009. "IT-Business Alignment: A Two-Level Analysis," Information Systems Management (26:4), pp. 338-349.

Teece, D. J., Pisano, G., and Shuen, A. 1997. "Dynamic Capabilities and Strategic Management," Strategic Management Journal (18:7), pp. 509-533.

Twentyman, J. 2011. "Rigid Rules on Use of Devices May Backfire," in: Financial Times. pp. Special Report: The Connected Business, p. 2, October 19.

van der Zee, J. T. M., and de Jong, B. 1999. "Alignment Is Not Enough: Integrating Business and Information Technology Management with the Balanced Business Scorecard," Journal of Management Information Systems (16:2), pp. 137-156.

Van Oorschot, K. E., Akkermans, H., Sengupta, K., and Van Wassenhove, L. N. 2013. "Anatomy of a Decision Trap in Complex New Product Development Projects," Academy of Management Journal (56:1), pp. 285-307. 
Venkatesh, V. 2000. "Determinants of Perceived Ease of Use: Integrating Control, Intrinsic Motivation, and Emotion into the Technology Acceptance Model," Information Systems Research (11:4), pp. 342-365.

Venkatesh, V., Morris, M. G., Davis, G. B., and Davis, F. D. 2003. "User Acceptance of Information Technology: Toward a Unified View," MIS Quarterly (27:3), pp. 425-478.

Venkatraman, N. 1989. "The Concept of Fit in Strategy Research: Toward Verbal and Statistical Correspondence," Academy of Management Review, (14:3), pp. 423-444.

Wade, M., and Hulland, J. 2004. "Review: The Resource-Based View and Information Systems Research: Review, Extension, and Suggestions for Future Research," MIS Quarterly (28:1), pp. 107-142.

Wagner, H.-T., Beimborn, D., and Weitzel, T. 2014. "How Social Capital among Information Technology and Business Units Drives Operational Alignment and IT Business Value," Journal of Management Information Systems (31:1), pp. 241-271.

Whittington, R. 2006. "Completing the Practice Turn in Strategy Research," Organization studies (27:5), pp. 613-634.

Wooldridge, B., and Floyd, S. W. 1990. "The Strategy Process, Middle Management Involvement, and Organizational Performance," Strategic Management Journal (11:3), pp. 231-241.

Wooldridge, B., Schmid, T., and Floyd, S. W. 2008. "The Middle Management Perspective on Strategy Process: Contributions, Synthesis, and Future Research," Journal of Management (34:6), pp. 11901221.

Xue, L., Ray, G., and Sambamurthy, V. 2012. "Efficiency or Innovation: How Do Industry Environments Moderate the Effects of Firms' IT Asset Portfolios?," MIS quarterly (36:2), pp. 509-528.

Yoo, Y., Henfridsson, O., and Lyytinen, K. 2010. "Research Commentary: The New Organizing Logic of Digital Innovation: An Agenda for Information Systems Research," Information Systems Research (21:4), pp. 724-735. 